\title{
MARINe ARCHAEOLOGY SURVEY of Redfish Bay Pipeline ProJect Nueces County, TeXas
}

\author{
Prepared for: \\ Project Consulting Services, Inc. \\ 1800 West Loop South, Suite 900 \\ Houston, Texas 77027
}

Prepared by:

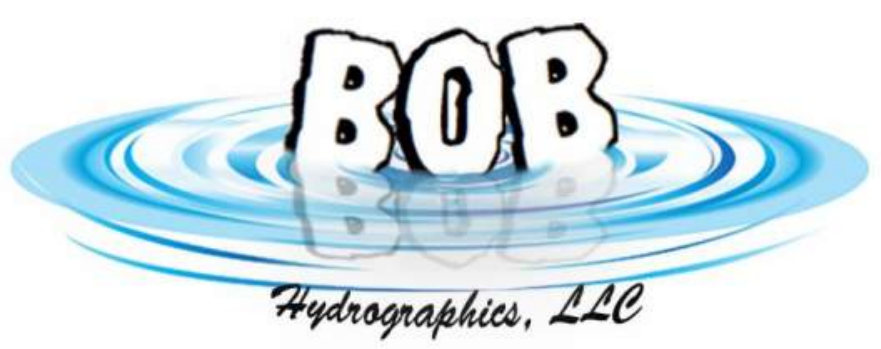

BOB Hydrographics, LLC

1315 Fall Creek Loop

Cedar Park, Texas 78613

Principal Investigator:

Robert Gearhart

February 2019 
BOB Project 2018-06

MARINE ARCHAEOLOGY SURVEY

OF REDFISH BAY PIPELINE PROJECT

NUECES COUNTY, TEXAS

Texas Antiquities Permit No. 8645

Prepared for:

Project Consulting Services, Inc. 1800 West Loop South, Suite 900

Houston, Texas 77027Prepared by:

BOB Hydrographics, LLC

1315 Fall Creek Loop

Cedar Park, Texas 78613

Principal Investigator:

Robert Gearhart

February 2019 


\section{Table of Contents}

Page

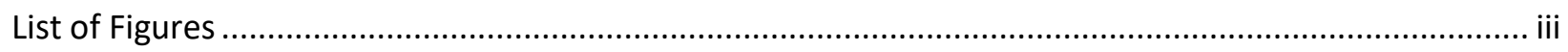

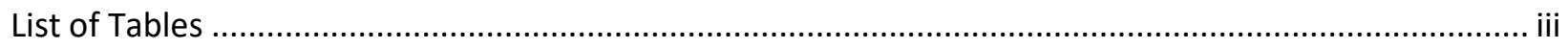

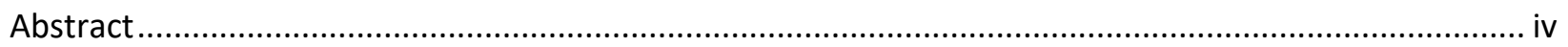

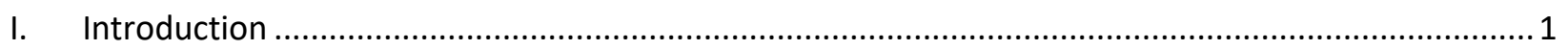

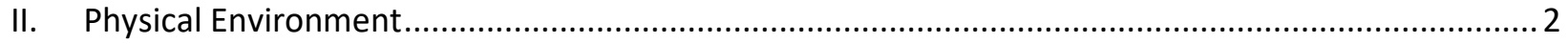

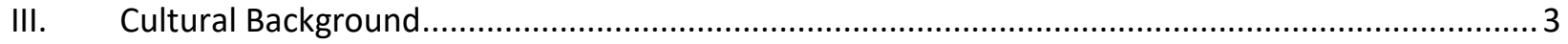

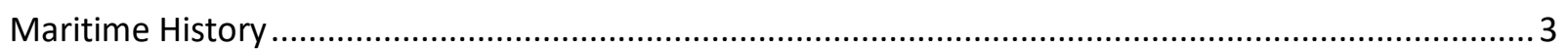

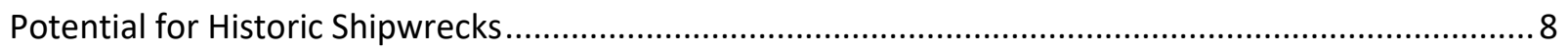

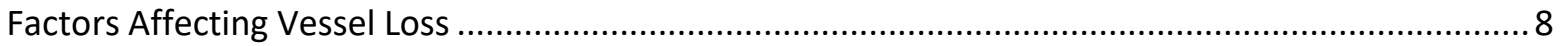

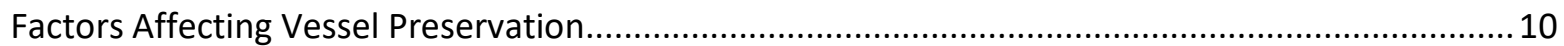

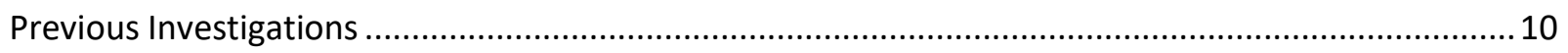

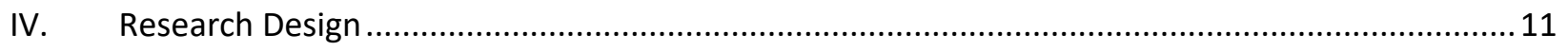

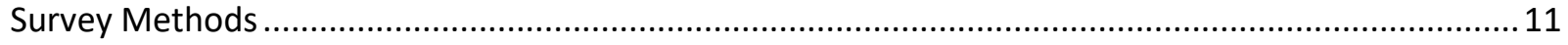

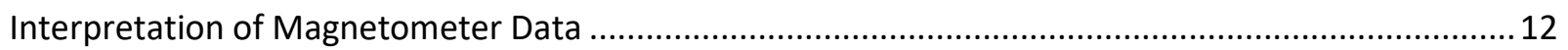

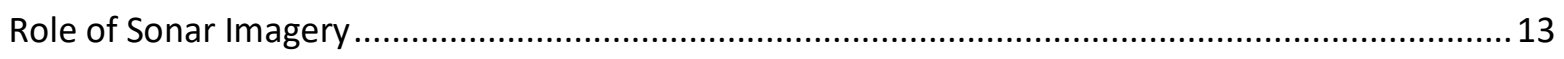

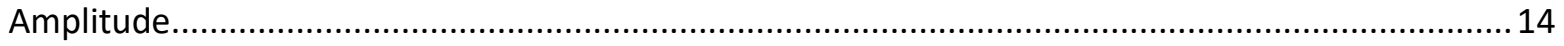

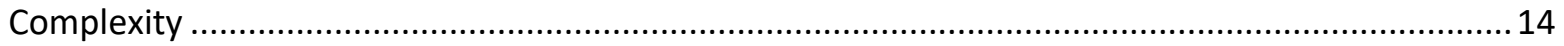

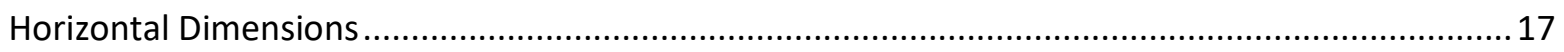

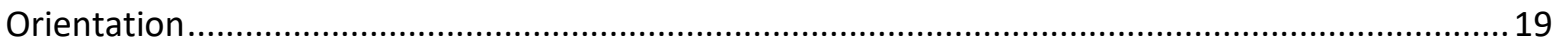

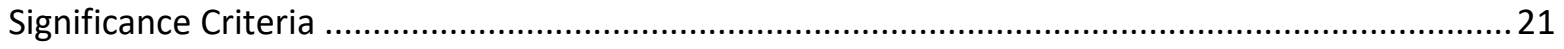

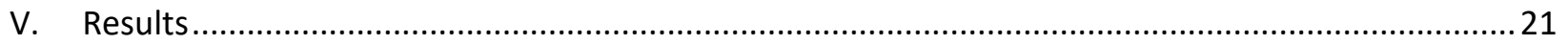

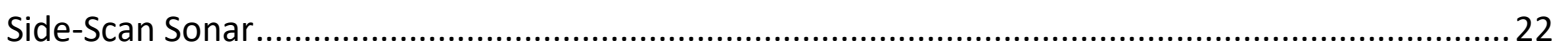

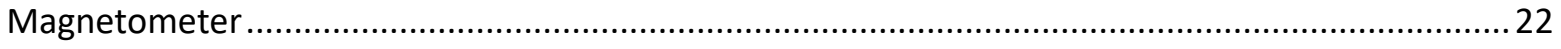

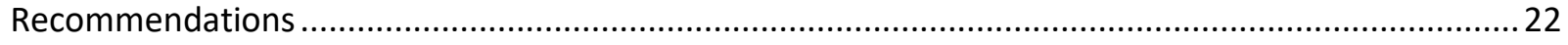

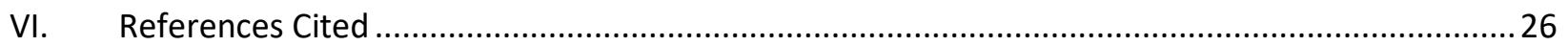

Appendix A: Side-Scan Sonar Mosaic (Not for Public Disclosure)..................................................... A-1

Appendix B: Magnetic Contours (Not for Public Disclosure) …...........................................................

Appendix C: Geophysical Targets Recommended for Avoidance (Not for Public Disclosure)....................-1

Appendix D: Texas Antiquities Permit 8645 and THC Concurrence Letter .......................................... D-1 


\section{List of Figures}

Page

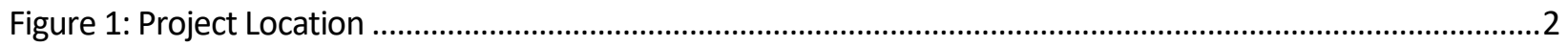

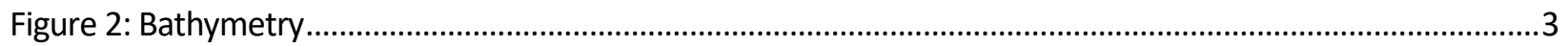

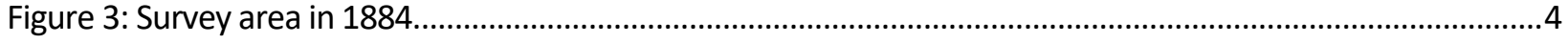

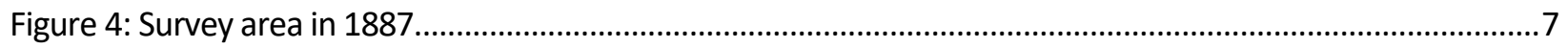

Figure 5: Example of a Verified Shipwreck Anomaly, Site 41CL92 ...................................................................16

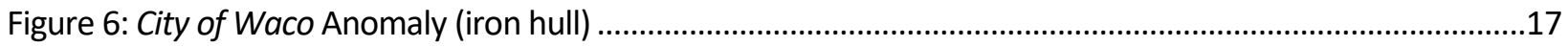

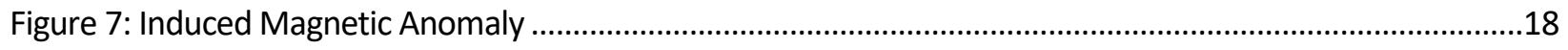

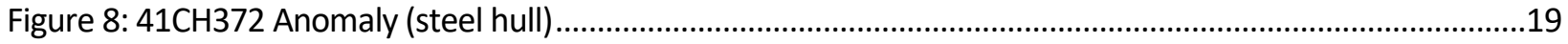

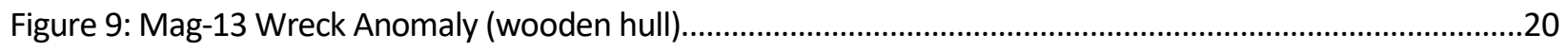

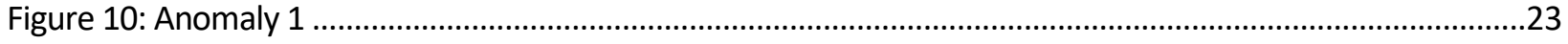

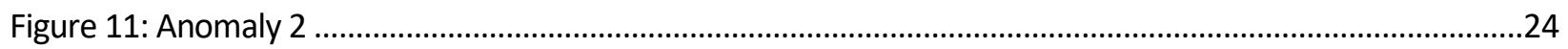

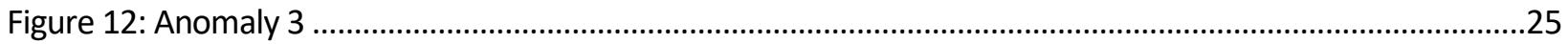

\section{List of Tables}

Page

Table 1: Wrecks Reported Within Three Miles of Survey Area …...................................................................9

Table 2: Previous Investigations Within Three Miles of the Survey Area .............................................................11

Table C-1: Geophysical Targets Recommended for Avoidance (Not for Public Disclosure) ................................ C-1 


\begin{abstract}
BOB Hydrographics, LLC (BOB) conducted a marine archaeological survey of a proposed pipeline project crossing Redfish Bay, in Nueces County. Project Consulting Services, Inc. contracted with BOB for this project, on behalf of the project sponsor, Axis Midstream Holdings, LLC. The survey spans portions of State Mineral Lease Tracts 321, 324, 325, 326, 327, and 328 between the community of Aransas Pass and Harbor Island. The Area of Potential Effect (APE) encompasses 203 acres. A total of 299 acres was surveyed, including petroleum-industry access channels connected to each end of the main survey corridor and a 50-meter buffer around the proposed APE as mandated by the Texas Historical Commission. Water depth ranged from 2.9-11.7 feet during the survey. Field investigations included a marine geophysical survey, performed under Texas Antiquities Permit 8645, on November 16 and 17, 2018. BOB assessed all geophysical data acquired by the survey to locate potential archaeological sites that could be affected by construction-related activities. No artifacts were collected during this survey. A review of cultural background determined that 5 marine archaeological investigations and, at least, 9 wrecks have been reported within 3 miles of the survey area. Analysis of survey results discovered 3 significant geophysical targets that might be potentially eligible as State Antiquities Landmarks and for the National Register of Historic Places. This study was completed in compliance with Section 106 of the National Historic Preservation Act (Public Law 89-665; 16 U.S.C. 470) and the Antiquities Code of Texas (Texas Natural Resource Code, Title 9, Chapter 191). The minimum reporting and survey requirements for marine archaeological studies conducted under a Texas Antiquities Permit are mandated by The Texas Administrative Code, Title 13, Part 2, Chapters 26 and 28, respectively. Project records will be curated by the Center for Archaeological Studies at Texas State University-San Marcos.
\end{abstract}




\section{Introduction}

BOB Hydrographics, LLC (BOB) conducted a marine archaeological survey of a proposed pipeline project crossing Redfish Bay, in Nueces County (Figure 1). Project Consulting Services, Inc. contracted with BOB for this project, on behalf of Axis Midstream Holdings, LLC. The 299-acre survey area is shaded red in Figure 1, including petroleum-industry access channels connected to each end of the main survey corridor. The access channels were dredged, thus do not have potential for historic shipwrecks; however, they were surveyed at the client's request. Areas shaded yellow in Figure 1 are proposed routes of horizontal directionally drilled pipes. The seafloor will not be disturbed in those areas. The Area of Potential Effect (APE) encompasses 203 acres as illustrated in Appendices A and B. The survey spans portions of State Mineral Lease Tracts 321, 324, 325, 326, 327, and 328 between the community of Aransas Pass and Harbor Island. Water depth ranged from 2.9-11.7 feet ( $\mathrm{ft}$ ) during the survey. Cultural resources investigations were required by the Texas Historical Commission (THC) because construction activities might affect historic cultural resources resting on or embedded in the seafloor. The results reported in this document will support an application for a United States Army Corps of Engineers Permit.

Geophysical survey was completed on November 16 and 17, 2018. The Principal Investigator conducted all fieldwork, with assistance from Ed Baxter, RPA, of Edward Baxter Consulting, and was solely responsible for archaeological data analysis and report preparation. The purpose of this study was to assess the archaeological potential of the survey area; although, no artifacts were collected. An archaeological assessment was conducted of all geophysical data acquired by the survey. Submerged archaeological sites, in this context, might be sunken or abandoned watercraft. Submerged historic remains may be eligible for nomination to the National Register of Historic Places (NRHP) or as State Antiquities Landmarks. A review of the cultural background determined that 5 marine archaeological investigations and, at least, 9 wrecks have been reported within 3 miles of the survey area. Analysis of geophysical survey results from this investigation discovered 3 targets potentially eligible for the State Antiquities Landmark or for the NRHP.

This study was completed in compliance with Section 106 of the National Historic Preservation Act (Public Law 89-665; 16 U.S.C. 470), requiring that the lead agency consider the effects of projects, receiving either permits or funding from the federal government, upon historic resources. This study also complies with the Antiquities Code of Texas (Texas Natural Resource Code, Title 9, Chapter 191), which provides for the protection of cultural resources on state lands. The survey area is publicly owned; therefore, a Texas Antiquities Permit was obtained prior to beginning fieldwork. Title 13, Part 2, Chapters 26 and 28 of The Texas Administrative Code mandates the minimum reporting and survey requirements, respectively, for marine archaeological studies conducted under Texas Antiquities Permits. Project records will be curated by the Center for Archaeological Studies at Texas State University-San Marcos.

This report is organized into six sections that provide context for interpreting the survey results and includes maps of magnetic contours and side-scan sonar imagery. Section II relies upon a combination of published literature and data collected by this survey to summarize the physical environment of the survey area. Section III summarizes the relevant cultural background within a 3-mile radius of the survey area, including maritime history, previous archaeological investigations, and the potential for intact 
archaeological sites. Section IV summarizes methods for conducting the survey and for processing and analyzing the geophysical data. Section $\vee$ presents an archaeological assessment of the geophysical data and provides recommendations specific to archaeological findings within the survey area. Bibliographic references cited in the text are included as Section VI.

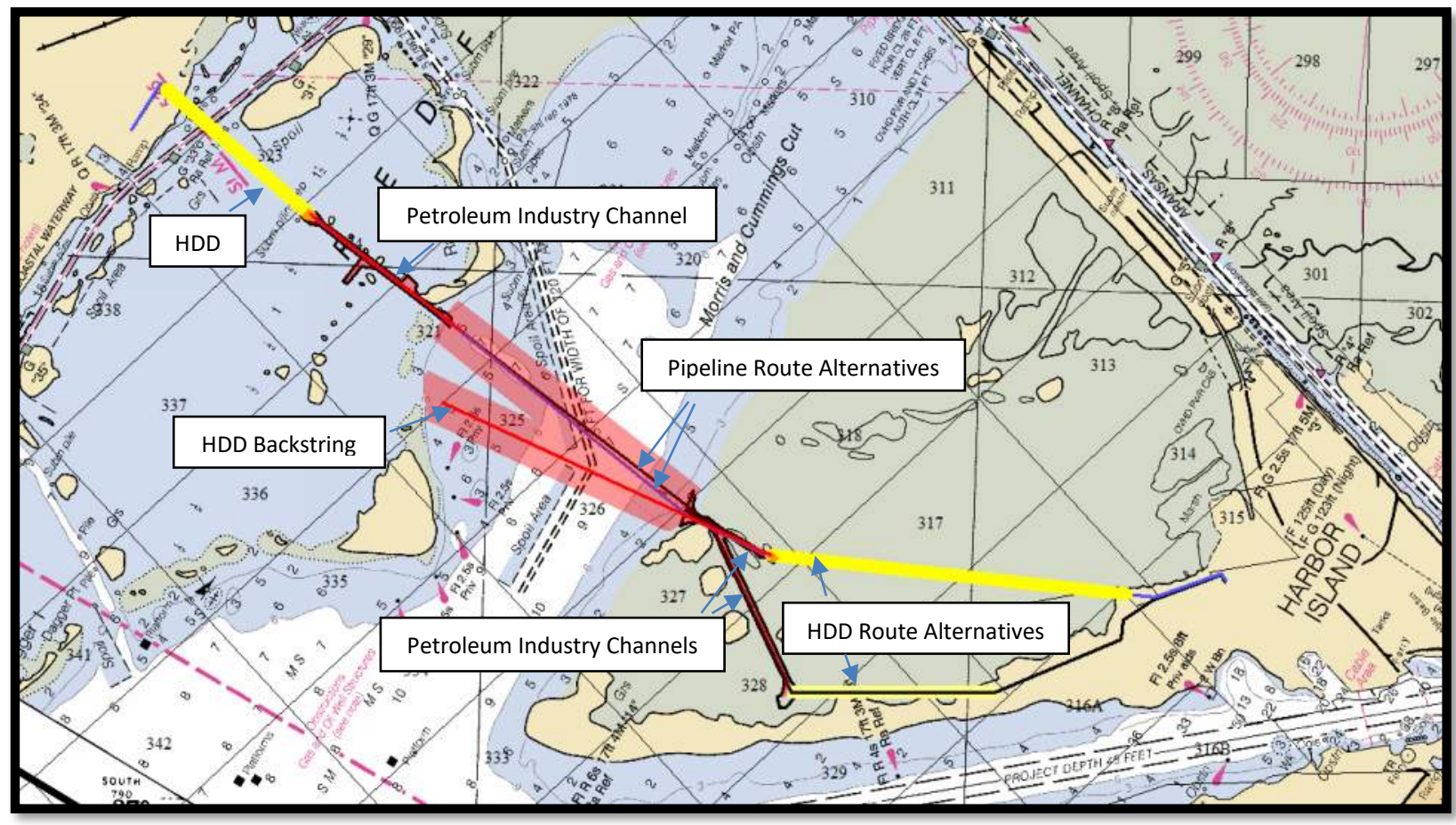

Figure 1: Project Location (survey area shaded red) Base Map: NOAA Chart 11314, Carlos Bay to Redfish Bay

\section{Physical Environment}

The survey area is located in Redfish Bay, between the mainland and Harbor Island, near Port Aransas, Texas. The National Oceanic and Atmospheric Administration (NOAA) charts the modern depth as 1-7 ft, Mean Lower Low Water (MLLW). Figure 2 shows water depths acquired during the present survey, ranging from 2.9 to $11.7 \mathrm{ft}$, overlaid on NOAA Chart 11314. The landscape of 1884 (United States Coast and Geodetic Survey 1884) is illustrated in Figure 3 for comparison. Historic water depth in the survey area was charted as about $1 \mathrm{ft}$ to $8.5 \mathrm{ft}$, Mean Low Water (MLW). The configuration of hydrography in and around the survey area has not changed significantly since 1884, except for the creation of navigation channels and associated spoil areas. The deepest parts of the survey area were navigable throughout the historic period.

The survey area is located entirely within the Redfish Bay State Scientific Area. Seagrasses are protected by law in this area and are managed by the Texas Parks and Wildlife Department. Survey lines were terminated in depths corresponding roughly with the 3-ft MLLW isobath in order to prevent damage to seagrasses from the outboard engine and the side-scan sonar towfish, both of which drafted about $2.5 \mathrm{ft}$. The outboard engine and sonar towfish were raised in shallow water to protect seagrass. 
Geomorphology of the survey area was influenced by sea level changes during and after the Late Wisconsin Glaciation. Continental glaciers held back significant amounts of water from the sea during the Late Wisconsin, resulting in a much lower sea level than exists today. Geologists have charted the timing and magnitude of sea level rise (e.g. Weise, et al. 1980: Figure 16). Sea level has risen more than $300 \mathrm{ft}$ since the last glacial low stand, about 20,000 to 22,000 years ago.

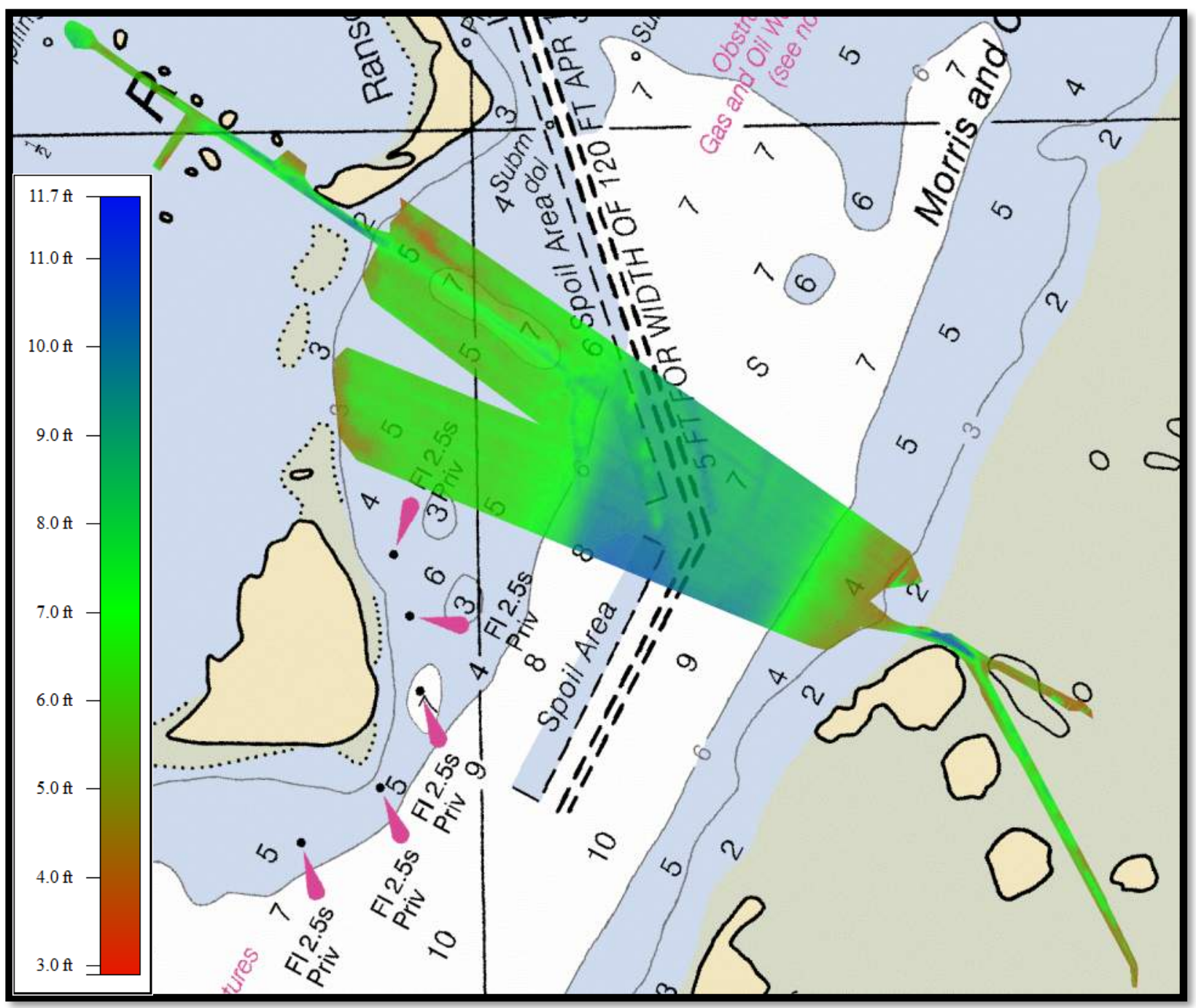

Figure 2: Bathymetry (ft); not tidally corrected

\section{Cultural Background}

\section{Maritime History}

Exploration of the Texas Coast began in 1519, when a Spaniard named Alonso Alvarez de Pineda led an expedition, on behalf of the governor of Jamaica, to map lands bordering the Gulf of Mexico. Pineda's map of the Gulf of Mexico shows inlets along the Texas Coast; however, there is no evidence that he entered or explored their shores. Pineda demonstrated there is no shortcut to Asia through the Gulf of 
Mexico. His logs also helped to identify the fastest sailing route between Vera Cruz and Havana (Weddle 1985; Chipman and Joseph 2010: 24-26).

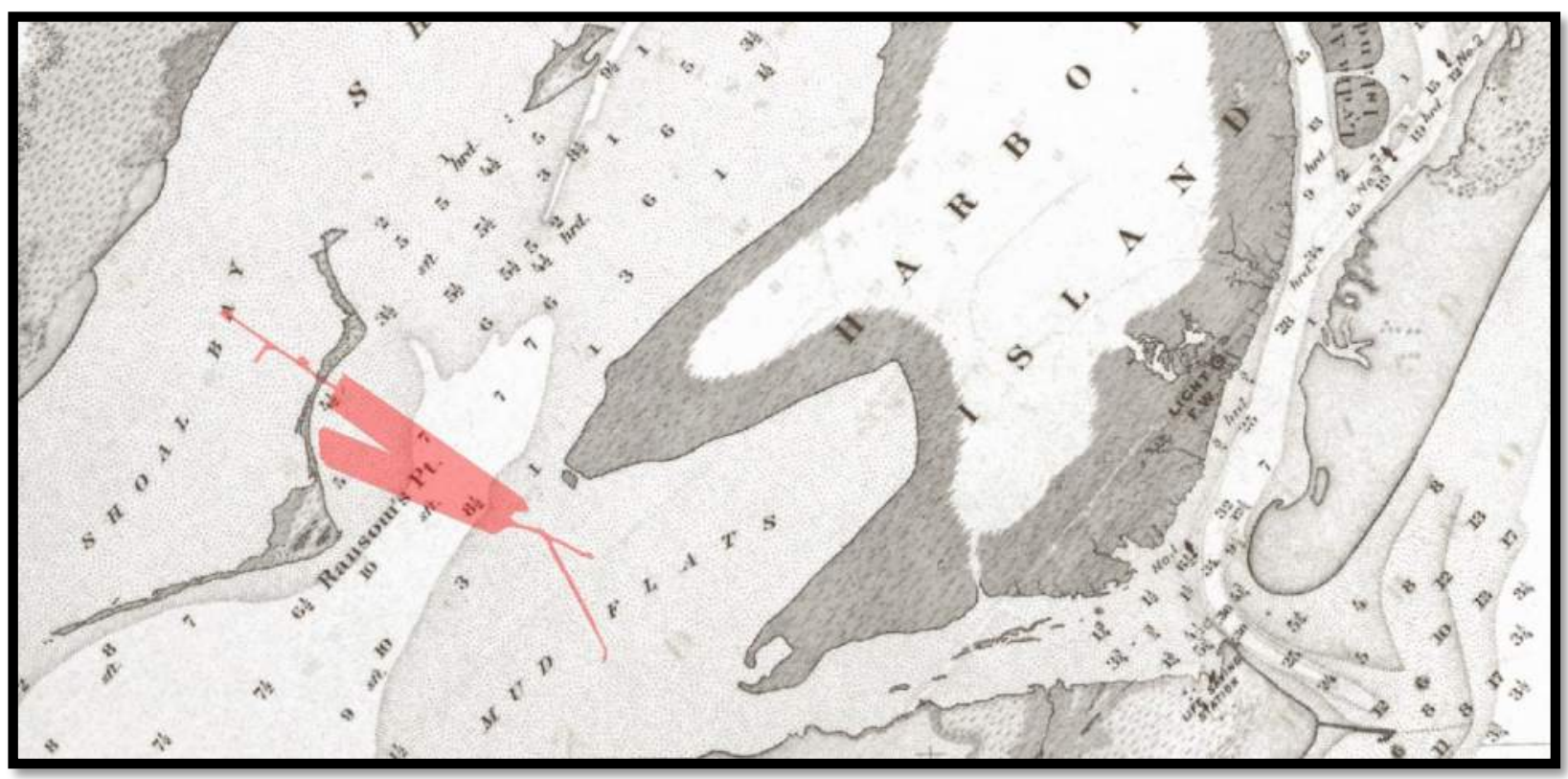

Figure 3: Survey area in 1884 (United States Coast and Geodetic Survey 1884, MLW)

The first Europeans known to explore the Texas Coast inland were survivors from the shipwrecked Pánfilo de Narváez expedition of 1527. Álvar Núñez Cabeza de Vaca and 80 other Spaniards sailed on makeshift rafts to what many believe was Galveston Island. Those who survived the first winter were enslaved by Native Americans. Only four men returned to tell their stories of wandering from tribe to tribe through what is now Texas and northern Mexico to the Pacific Coast, eventually reaching Mexico City after eight years. Cabeza de Vaca published his story in 1542 upon returning to Spain (Covey 1983).

The Spanish silver fleet, sailing out of Vera Cruz, conducted steady trade with Havana for about 250 years, until 1790. Their ships typically followed either a northern route, paralleling the coast, or crossed the central Gulf of Mexico. Seasonal changes in wind and current patterns determined their choice of routes (Lugo-Fernandez et al. 2007). The northern route occasionally imperiled Spanish flotillas when storms pushed them toward the coast.

In 1554 a fleet of three Spanish ships wrecked on the Texas Coast near the Port Mansfield Channel, about 70 miles south of Mustang Island. The loss of the ships, Santa María de Yciar, San Esteban, and Espíritu Santo, led in the short term to an intensive 2-month salvage effort by García de Escalante Alvarado to recover their valuable cargos (McDonald and Arnold 1979). The loss of nearly $300 \mathrm{crew}$ and passengers (only 32 people returned to Vera Cruz), including women and children, prompted longer range plans for more detailed explorations of the Gulf Coast. Guido de Lavazares was chosen to lead an expedition of three ships with orders to explore the entire coast from Rio de las Palmas to the Florida Keys. Lavazares arrived on the Texas Coast in the fall of 1558 at the latitude of present-day Kingsville. From that point, he followed the coast, stopping in what is believed to be Matagorda Bay, where he formally claimed the 
region as a Spanish possession (Chipman and Joseph 2010: 48; Weddle 1991:100-103). A second expedition by Gonzalo Gayon followed the Gulf Coast in the opposite direction, from Florida to Texas, within a year or two of Lavazares.

Spain understandably did little to explore or develop settlements along the Texas Coast until their claims were challenged by other nations. Their population and trade centers were located far to the south in Mexico. Instead, they focused on inland explorations and establishment of missions to Christianize the natives. But then, in 1685, René Robert Cavelier, Sieur de La Salle arrived in Matagorda Bay with 300 colonists. By the time Spain heard talk of a French colony in the heart of their territory, La Salle's Fort St. Louis was already doomed, through a series of unfortunate events, to failure. The expedition lost one of three ships upon their arrival. A second ship returned to France with a group of colonists. While La Salle was attempting to find the Mississippi River with an overland expedition, their last ship, La Belle, grounded during a storm and was lost in Matagorda Bay. La Salle was murdered by his own men, and, with no way to return to Europe, those remaining at Fort St. Louis eventually perished (Weddle 1991).

Despite La Salle's failure to establish a lasting French presence, rumors of the French incursion quickly reached Spain. Spain mounted an intensive exploration of the Texas Coast to find and rout out the unwelcome intruders while simultaneously charting their own, relatively unknown, possessions there. Weddle (1991:68) summarized the effect of La Salle's arrival on the Spanish royal court as inspiring "the most intense coastal reconnaissance ever made in the Gulf of Mexico. In five coastal voyages spanning three years, there were few rivers and bays that had not been examined." One such voyage explored the area of Aransas Pass. Martín de Rivas and Pedro de Iriarte sailed north from Veracruz in 1686, reaching Aransas Pass in March of 1687. They named the pass Rio de San Joseph, charted its depths, and spent several days exploring the surrounding area (Weddle 1991). The abandoned remains of Fort St. Louis eventually were discovered by Alonso de León in 1689, upstream from Lavaca Bay on Garcitas Creek.

In 1764, Jose de Escandon was ordered by the viceroy of New Spain, Joaquín de Montserrat, Marqués de Cruillas, to investigate rumors of English settlement on islands of the Texas Coast, not far from the mouth of the Nueces River. Escandon reported about the shoreline from Tampico to the Trinity River, based largely on testimony of a seaman, Joseph Garabito, who had made many trips up and down the coast. He reported that no English were found and that there was no place along that stretch of coast suitable for the English to establish a settlement (Bolton 1915: 104).

Shortly thereafter, in 1766, Diego Ortiz Parrilla was commissioned to explore the islands of the lower Texas Coast, and in particular what is now known as Padre Island. Parrilla was unable to personally explore the coast above the Nueces River, due to flooding from a hurricane, so he diverted inland to La Bahía del Espíritu Santo (Goliad) where he recorded extensive testimony regarding that portion of the coast between Nueces and the Trinity River. The soldiers of La Bahía interviewed by Parrilla had extensive knowledge of the coast between Matagorda Bay and the Nueces River, having made frequent trips to investigate wrecked vessels and pursue mission Indians (Bolton 1915: 104-106).

Copano Bay was one of the earliest maritime destinations inside of Aransas Pass. Its origin as a place of commerce may be linked to the relative ease of overland travel between Copano Bay and Spanish 
settlements at San Antonio (Presidio San Antonio de Béxar in 1716) and Goliad (Presidio La Bahía in 1749). Huson points out that Copano was the "nearest port and had no great river or stream between it and the settlements at San Antonio, or Rosario and La Bahía Mission, required to be crossed in carting between this port and either town. There is no question that this port was regularly used to supply Bexar and La Bahía" (Huson 1935: 6). The Port of Copano was officially opened for trade in 1785 with a collector of customs located at Goliad. Huson goes on to say that "the Mission of Nuestra Senora del Refugio was established [in 1793] to protect this port from pirates and smugglers" (ibid.).

Other early bay settlements dependent largely upon trade through Aransas Pass included the original town of Aransas, charted by Hunt and Randel (1839) on Live Oak Point (present site of Fulton and Rockport; see also Folsom 1842: 204); Lamar, at the entrance to Copano Bay opposite Live Oak Point; and a later version of Aransas on St. Joseph's Island (Marcy 1855). Marcy indicated channels and soundings leading from Aransas Pass to each town, as well as wagon roads leading to various points inland. All of the above bay shore communities were accessed by sea primarily through Aransas Pass and to a lesser extent through Corpus Christi Pass, and Cedar Bayou, also known as Espíritu Santo Inlet (Hunt and Randel 1839). Marcy did not chart soundings for Cedar Bayou, as he did for the other two inlets, suggesting it was of less commercial importance.

The first settlement at what is now Corpus Christi was founded as a trading post in 1839 by Henry Kinney and William Aubrey (Long 2010). The first town to be organized at the site was Grayson, shown on Hunt and Randel's (1839) chart and mentioned by Folsom (1842: 204) as "a town recently laid off on the south side of Corpus Christi Bay." By 1845, when General Zachary Taylor's army landed there during the Mexican American War, the town had become known as Corpus Christi. Corpus Christi was used extensively during the war to land troops and supplies bound overland for Mexico. Taylor's troops and supplies were lightered to shallow-draft steamers at Aransas Pass, then ferried through the channel behind St. Joseph's Island, across Redfish Bay, including the present survey area, and finally into Corpus Christi Bay. The channel between Aransas Pass and Redfish Bay (see Figure 4) was deepened by dredging in 1874 and became known as the Morris Cummings Cut (Alperin 1977: 126).

Morgan Line steamboats began regular runs between New Orleans and the Texas Coast following the Civil War. This trade was subsidized by contracts with the federal government to deliver mail. Morgan negotiated four-year contracts in 1867 for service three times per week between New Orleans, Galveston and Indianola (in Matagorda Bay) and for a coastal route between Galveston, Matagorda, Aransas Bay, and Brazos Santiago. By 1875, Morgan Line steamships were running weekly, from June to October, and twice-weekly, from October to June, between Brashear, Louisiana (Morgan City) and Rockport, by way of Aransas Pass. The Morgan Line offered the only regular steamship service along the Texas Coast. Morgan Line steamers averaged one trip through Aransas Pass every 10 days over a period of five years, from 1871 through 1876 (Hoyt 1990: 9-16). While important to the regional economy, the Morgan steamship visits represented less than half of offshore maritime trade (measured in vessel transits) through Aransas Pass. Over the period from 1866-1877, ships crossed the bar at Aransas Pass 1,880 times, averaging 1 arrival and 1 departure every 4-5 days (Kuehne 1973: cited in Hoyt 1990: Appendix A). 
Hoyt (1990: Appendix B) itemized imports and exports through Aransas Pass for a short part of the 1880's. His research provides a snapshot of the quantity and variety of commerce through the pass at that time. Cattle products greatly dominated exports, including: tinned beef, hides (wet and dry), tallow, bones, blood, hair, shin bones, horns, knuckles, hoofs, neat's-foot oil, and a small number of live cattle. Also exported was a large quantity of wool, and lesser quantities of ixtle fiber, fish and turtles, cotton, hemp, lead, merchandise, sheep, horses, hogs, and ore. Imports were dominated by general merchandise, lumber, and shingles. Other items imported included: steel rails, coal oil, coal, fire brick, cedar piles, salt, sheep, and a small number of calves, and hogs.

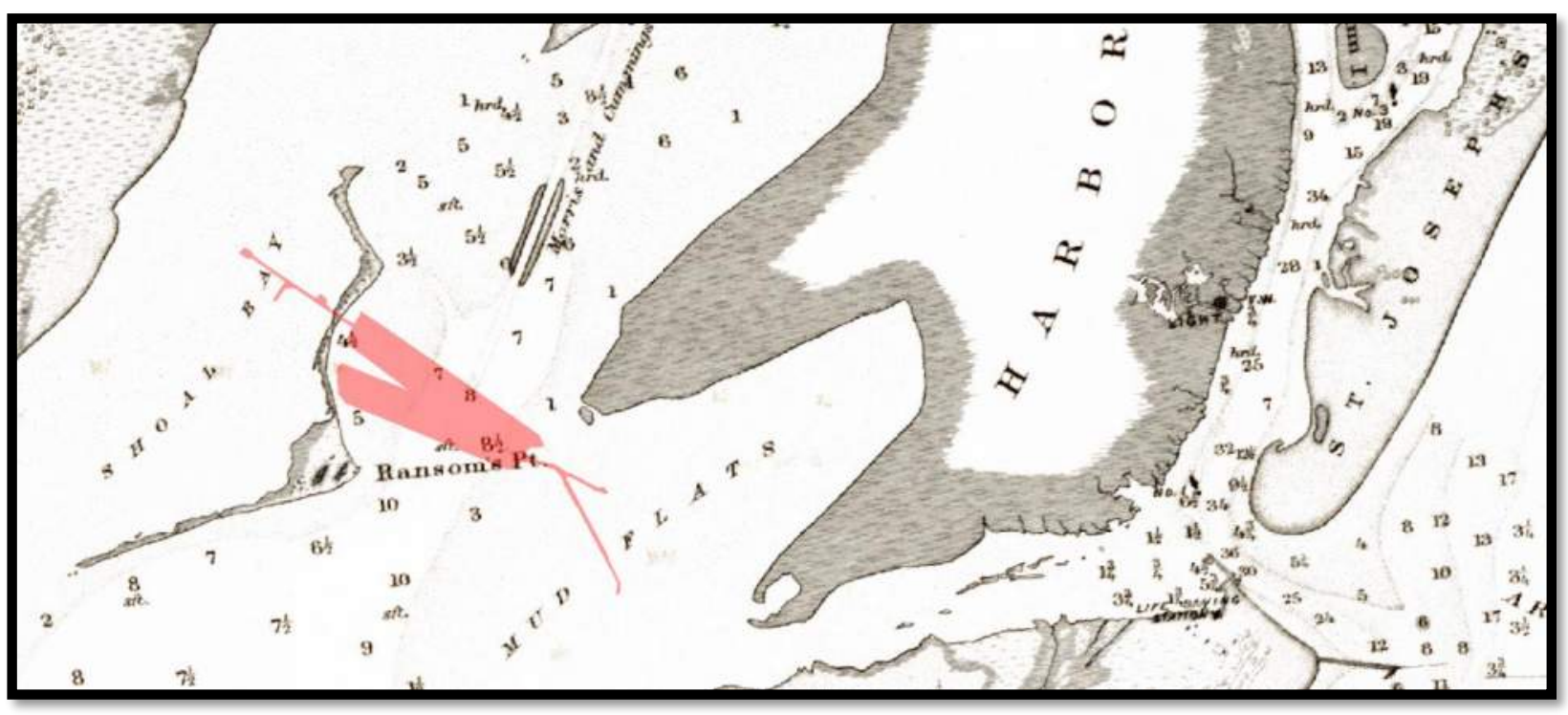

Figure 4: Survey area in 1887 (United States Coast and Geodetic Survey 1887, MLW)

The bar at Aransas Pass became so shallow in 1878 that steamships could not enter the harbor. Federal involvement with navigation improvements in Corpus Christi Bay began with passage of the Rivers and Harbors Act of 1878. The following year, funds were authorized for deepening the outer bar channel at Aransas Pass, which was completed in 1885. The first direct channel between Aransas Pass and Corpus Christi, the Turtle Cove Channel, was dredged to a depth of $8.5 \mathrm{ft}$ by 1909. Completion of the Turtle Cove Channel bypassed the Morris and Cummings Cut, so commercial traffic through the survey area would have decreased significantly after this time. By 1919 the current stone jetties at Aransas Pass had been completed, which aided efforts to maintain the Aransas Pass Channel (Alperin 1977: 129-132) and removed the safety concerns associated with shifting sand bars at the harbor entrance. In 1922 the Turtle Cove Channel was renamed the Corpus Christi Ship Channel. The channel has been deepened and widened multiple times since then to accommodate larger ships.

Improvements to channels coincided with steady advancements in the safety of ships during the first half of the twentieth century. Sailing vessels were being replaced rapidly by safer, machine-powered vessels. By 1910, sailing ships comprised less than half of annual losses of U.S. merchant vessels for the first time, and by the end of World War II, only 2-percent of nationwide losses were sailing ships. This is significant, because sailing ships were at a higher risk of running aground than machine-powered vessels. At the same time that machinery was replacing wind power, more durable metal hulls gradually were replacing wooden hulls, a 
trend which had accelerated by the turn of the century. Nevertheless, at least 93 percent of all U.S. merchant vessels lost through the end of World War II were made of wood (Gearhart 2011a).

\section{Potential for Historic Shipwrecks}

Europeans have navigated the Texas Coast for the past 500 years. Visits increased after 1685 as Spain and France competed for possession of the region. Europeans probably made regular trips through Aransas Pass by the mid-1700's to supply the mission and presidio at Goliad by way of Copano Bay. The Port of Copano was officially opened in 1785 along with a Customs House at Goliad. By 1839 traffic through Aransas Pass was visiting other coastal communities including Lamar, Aransas, and Kinney's Trading Post at Grayson (soon renamed Corpus Christi). The volume of trade through Redfish Bay and the survey area would have steadily grown after Corpus Christi was founded, including vessel traffic supplying US troops during the war with Mexico in the 1840s, until the Morris and Cummings Cut was abandoned around 1909. Use of the survey area by fishermen and hunters has continued up to the present day. The area has a potential for wrecks driven ashore by storms throughout the historic period.

Shipwrecks reported within 3 miles of the survey area are included in Table 1. Sources consulted for Table 1 include the THC Texas Archaeological Sites Atlas (Atlas); the NOAA Automated Wreck and Obstruction Information System (AWOIS) database; a shipwreck database compiled by PBS\&J; and historic maps from the Texas Historical Overlay (Foster, et al. 2006). There also is potential for unreported wrecks dating back to the time of early European navigation through the area.

The THC Atlas contains reports of shipwrecks from historic records. The AWOIS database is maintained by NOAA to support the charting of coastal areas. AWOIS tends to report recent shipwrecks; however, historic wrecks are included. Positions for wrecks in AWOIS are usually more accurate than those from historic records, although positions pre-dating the era of satellite position systems can vary considerably from actual locations. A group of archaeologists, including this author, assembled the PBS\&J database, in part, based on information gathered from charts, historical reports, THC files, and AWOIS. The PBS\&J database focuses primarily on well-documented commercial wrecks postdating 1850.

At least 9 shipwrecks have been reported within a 3-mile radius of the Survey Area by one or more of the sources listed above. Positions reported in historical accounts are often imprecise, and archaeologists have yet to record any of the wrecks listed in Table 1.

\section{Factors Affecting Vessel Loss}

Factors contributing to the loss of watercraft vary depending on environment conditions. Historic government statistics, summarized by Gearhart, et al. (1990: Volume IV, 59-61), categorized vessel casualties, including most accidents and incidents resulting in injury or loss of property, and reported the value of losses incurred. A total loss was reported if the hull could not be saved. These statistics do not reflect the degree to which cargo and vessels were salvaged. Types of casualties included foundering, stranding, collision and other (fires, boiler explosions, injuries, mechanical failures, etc.). 
Table 1: Wrecks Reported Within Three Miles of Survey Area

\begin{tabular}{|c|c|c|c|c|c|c|}
\hline $\begin{array}{c}\text { Name of } \\
\text { Vessel }\end{array}$ & $\begin{array}{l}\text { THC } \\
\text { No. }\end{array}$ & $\begin{array}{c}\text { PBS\&J } \\
\text { No. }\end{array}$ & $\begin{array}{c}\text { AWOIS } \\
\text { No. }\end{array}$ & Description & Date Lost & $\begin{array}{l}\text { Position } \\
\text { Accuracy }\end{array}$ \\
\hline $\begin{array}{l}\text { Bahia } \\
\text { Honda }\end{array}$ & 1232 & 559 & 4998 & 50-ft wooden shrimp boat & Pre-1968 & $\begin{array}{l}0.25 \\
\text { miles }\end{array}$ \\
\hline Kaiser & - & - & 7855 & Unknown vessel type & unknown & unknown \\
\hline Tramp & 2186 & 1382 & - & $\begin{array}{l}\text { Gas screw; broke from } \\
\text { mooring in Port Aransas } \\
\text { during hurricane on } \\
\text { September 14th; total loss }\end{array}$ & 1919 & unknown \\
\hline Unknown & 1087 & 612 & 4875 & Unknown vessel type & Pre-1977 & unknown \\
\hline Unknown & - & - & 5026 & Unknown vessel type & unknown & unknown \\
\hline Unknown & - & - & 5967 & Unknown vessel type & unknown & unknown \\
\hline Unknown & - & - & 10427 & Unknown vessel type & unknown & unknown \\
\hline Unknown & - & - & 10429 & Unknown vessel type & unknown & unknown \\
\hline Unknown & 1228 & - & - & Unknown vessel type & 1977 & unknown \\
\hline
\end{tabular}

Foundering was the primary mechanism of vessel loss in navigable waters. The Annual List of Merchant Vessels of the United States (United States Department of the Treasury 1906-1946) defined foundering as leaking or capsizing of vessels. Foundering accounted for about 6 percent of historic vessel losses. Despite its low rate of occurrence, recovery from foundering was less likely than from any other type of casualty. Fifty-four percent of all foundered vessels were reported as totally lost.

Stranding was the primary mechanism of loss in shoal waters and was, by far, the most common type of shipwreck during the historic period. Stranding (or grounding) accounted for 64 percent of total losses reported by the U.S. Lifesaving Service for the period 1876 through 1914 (Gearhart, et al. 1990: Volume IV, 59-61). Stranding occurred where the water was too shallow for navigation, including shorelines, harbor bars and reefs. Forty-six percent of stranding events resulted in a total loss (Gearhart 1990: Volume IV, 59-61). Stranding is the most likely source of shipping losses in the survey area.

Severe weather accounted for 55 percent of total losses reported by the U.S. Lifesaving Service from 1876 through 1914. Almost half of all losses from foundering were caused by weather, compared with two thirds of losses from stranding. Mariners had short warning of approaching storms prior to modern weather forecasting. The central Texas Coast can experience hazardous weather conditions throughout much of the year. Hurricane season lasts from late June through October. Hurricane-force winds can devastate ships caught unprepared. During the winter, severe cold fronts affect the Texas Coast. These 
"Northers" may have winds exceeding 50 miles per hour, generating dangerous waves, and can last 2436 hours (McGowen 1976:19-23, 94).

\section{Factors Affecting Vessel Preservation}

Preservation of sunken watercraft depends mainly upon their composition and the extent of their burial in the seafloor. Vessels may become partially buried soon after sinking due to the combined effects of storm-induced current scour, liquefaction of sediments, and the ship's weight pressing down on a waterlogged substrate. Ships made of metal are equally susceptible to burial as wooden hulls, but metal hulls remain exposed much longer than wooden ones in saline waters along the Texas Coast. Exposed wooden components tend to disintegrate quickly where wood-boring organisms thrive. Biological organisms and water saturation weaken the wood, which is then more easily disarticulated and laid flat or removed by fishing trawlers and storm waves. Burial promotes long-term preservation of wood by creating an oxygen-deprived environment, which limits biological activity. Given a sufficient quantity of weakly-consolidated sediment, a significant portion of a hull might become preserved in this manner.

Iron corrodes five times faster in seawater than when buried on land. Iron artifacts tend to become concreted when calcium carbonate from the seawater cements adjacent materials, such as rock and sand, or even other artifacts, to the iron object. Prolonged oxidation can leach out most or all iron mineral, leaving only a carbonate mold of the original artifact (Hamilton 1999). Iron and steel hulls, nevertheless, can survive seawater exposure for well over a century.

\section{Previous Investigations}

Five marine archaeological surveys have been completed within 3 miles of the survey area (Table 2). Abstracts for these studies are available on the THC Atlas. None of these studies overlap the survey area.

PBS\&J completed an extensive study of the Corpus Christi and La Quinta Ship Channels from 2000-2001 on behalf of the U.S. Army Corps of Engineers (Enright, et al. 2003). Marine remote-sensing and archeological diving investigated areas potentially affected by expansion of both federal navigation channels. Geophysical survey of 5,610 acres discovered 13 potentially significant anomalies, which were further investigated by divers. One target was determined to be a historic shipwreck, believed to be the Dayton (designated 41NU291) a steamboat that sank as a result of a boiler explosion in 1845. A second shipwreck, Utina (41NU292) was discovered adjacent the southern jetty at Aransas Pass by this survey.

PBS\&J completed a 306-acre remote-sensing survey nearby for IBC Petroleum in 2001. Their survey investigated six proposed well pads and two proposed pipeline routes in Corpus Christi Bay. No potentially significant geophysical targets were discovered within 50 meters $(\mathrm{m})$ of the proposed undertakings (Hedrick and Gearhart 2002).

In 2001, PBS\&J completed a 294-acre geophysical investigation of a 3.5-mile corridor centered on Corpus Christi Bayou and the historic Morris and Cummings Cut in the northern half of Redfish Bay (Hedrick 2001). The study was conducted on behalf of Cabot Oil in connection with three Corps of Engineers permit applications for proposed well pads and pipeline routes. Marine remote-sensing investigations included the collection and assessment of magnetic, side-scan sonar, and bathymetric data along 19 miles of survey transects. 
In 2006, PBS\&J completed a 48-acre geophysical survey on behalf of Boss Exploration and Production Corporation in connection with a proposed flow line in Corpus Christi Bay (Hoskins, et al. 2006). No potentially significant geophysical targets were discovered by their investigations, and PBS\&J recommended that no further archeological investigations should be required.

In 2008, Panamerican Consultants, Inc. completed a 10-acre survey of two proposed well pads and two proposed flow line corridors in Corpus Christi Bay (James and Faught 2008). The investigation was conducted on behalf of Cinco Natural Resources Corporation under the direction of Belaire Environmental, Inc. No potentially significant geophysical targets were discovered, and no additional archaeological investigations were recommended.

Table 2: Previous Investigations Within Three Miles of the Survey Area

\begin{tabular}{|c|c|c|c|}
\hline $\begin{array}{l}\text { Antiquities } \\
\text { Permit }\end{array}$ & $\begin{array}{l}\text { Principal } \\
\text { Investigator }\end{array}$ & Report Title & Sponsor \\
\hline 2407 & $\begin{array}{l}\text { Robert } \\
\text { Gearhart, } \\
\text { PBS\&J }\end{array}$ & $\begin{array}{l}\text { Marine Remote-Sensing Survey and Diving } \\
\text { Assessment for Historic Properties Investigations, } \\
\text { Corpus Christi Ship Channel Improvements and La } \\
\text { Quinta Ship Channel Extension, Corpus Christi Bay, } \\
\text { Texas }\end{array}$ & $\begin{array}{l}\text { U.S. Army Corps } \\
\text { of Engineers }\end{array}$ \\
\hline 2629 & $\begin{array}{l}\text { Robert } \\
\text { Gearhart, } \\
\text { PBS\&J }\end{array}$ & $\begin{array}{l}\text { Remote-Sensing Investigations of Six Proposed } \\
\text { Well Pads and Two Proposed Pipeline Routes in } \\
\text { Corpus Christi Bay, Nueces County, Texas }\end{array}$ & IBC Petroleum \\
\hline 2664 & $\begin{array}{l}\text { Layne } \\
\text { Hedrick, } \\
\text { PBS\&J }\end{array}$ & $\begin{array}{l}\text { Remote-Sensing Investigations of Corpus Christi } \\
\text { Bayou and the Morris and Cummings Cut in Red } \\
\text { Fish Bay, Aransas County, Texas }\end{array}$ & Cabot Oil \\
\hline 4118 & $\begin{array}{l}\text { Jenna } \\
\text { Enright, } \\
\text { PBS\&J }\end{array}$ & $\begin{array}{l}\text { Marine Remote-Sensing Survey for a Proposed } \\
\text { Flow Line from Existing Platform 343-1 to Well ST } \\
\text { 344-2, Corpus Christi Bay, Nueces County, Texas }\end{array}$ & $\begin{array}{l}\text { Boss Exploration } \\
\text { \& Production } \\
\text { Corporation }\end{array}$ \\
\hline 4852 & $\begin{array}{l}\text { Stephan } \\
\text { James, } \\
\text { Panamerican } \\
\text { Consultants }\end{array}$ & $\begin{array}{l}\text { Submerged Cultural Resources Remote Sensing } \\
\text { Survey of Proposed Wellheads and Pipelines in } \\
\text { State Lease Tract 345, Corpus Christi Bay, Nueces } \\
\text { County, Texas }\end{array}$ & $\begin{array}{l}\text { Cinco Natural } \\
\text { Resources } \\
\text { Corporation }\end{array}$ \\
\hline
\end{tabular}

\section{Research Design}

\section{Survey Methods}

The purpose of the survey was to map geophysical anomalies that might have historical significance. In the context of submerged lands, historical significance typically, although not necessarily, refers to association with historic shipwrecks. The primary instrument for locating potential shipwrecks in buried contexts is the magnetometer. Exposed shipwrecks are visible in side-scan sonar imagery; however, historic wrecks in Texas bays and shallow areas in the Gulf of Mexico are more often buried. Vessels predating World War II tend to be constructed of wood, which quickly deteriorates when exposed to wood-loving organisms common to warm saline environments. Nevertheless, buried portions of wooden 
hulls can retain a high level of artifact preservation and historic integrity. Wrecks exposed above the mudline for more than a few years tend to be constructed of materials other than wood.

Geophysical investigations were designed to meet or exceed the following minimum standards of the THC for archaeological survey of state-owned submerged lands (Texas Administrative Code, Title 13, Part 2, Chapter 28, Rule 28.6): 1) the survey must be conducted under a Texas Antiquities Permit issued by the THC; 2) the survey line interval cannot exceed 20 m (30 m when greater than 3 nautical miles offshore); 3) bottom-disturbing activities must be avoided within $50 \mathrm{~m}$ of potentially significant targets ( $150 \mathrm{~m}$ when more than 3 nautical miles offshore); 3 ) the survey area must extend beyond the limits of bottomdisturbing activities by the width of the avoidance margin; 4) survey instrumentation must include a marine magnetometer, a high-resolution side-scan sonar, and a recording fathometer all of which must record data digitally to electronic storage media; 5) survey instrumentation should be interfaced with a positioning system having accuracy comparable or better than a differential global positioning system (GPS) receiver; 6) the magnetometer must be towed within $6 \mathrm{~m}$ of the marine bed and should sample at least once per second; 7) the side-scan sonar should operate at a minimum frequency of 300 kiloHertz $(\mathrm{kHz}) ; 8)$ the positioning system should sample at least once per second; and 9) no artifact collection is permitted.

The survey was completed by BOB on November 16-17, 2018. The survey was conducted from a 20-foot hydrographic survey vessel. BOB's field crew included Robert Gearhart (Principal Investigator) and Ed Baxter, RPA of Edward Baxter Consulting. The Principal Investigator was solely responsible for archaeological data analysis and report preparation.

Geographic positions were acquired using a Hemisphere AtlasLink GPS receiving L-Band corrections. Horizontal position estimates for each sensor were recorded in real time. Positions are based on the Universal Transverse Mercator Coordinate System (Zone 14 North, meters). All data, except sonar, was logged in Hypack navigation software. Bathymetry data were acquired using a Teledyne-Odom CV100 recording fathometer equipped with a $200-\mathrm{kHz}$, 4-degree transducer. The CV100 transducer was mounted on a pole $1.2 \mathrm{ft}$ below water level and offset $2.3 \mathrm{ft}$ to port and $2.7 \mathrm{ft}$ aft of the GPS. Lead-line soundings were used to calibrate the fathometer. A Geometrics 882 magnetometer was towed on the sea surface $50 \mathrm{ft}$ aft of the survey boat. The magnetometer was towed from a point at the stern, offset $4.9 \mathrm{ft}$ starboard and $8.8 \mathrm{ft}$ aft of the GPS.

Side-scan sonar data was acquired using a 412-kHz, Edgetech 4125 system towed from the survey vessel's port side. The sonar transducers were offset approximately $6.3 \mathrm{ft}$ starboard and $2.7 \mathrm{ft}$ aft of the GPS. Geographic positions were embedded in the digital sonar data as it was recorded. Sonar data was recorded using Edgetech's Discover acquisition software along a 25-m-wide (82-ft) swath overlapping with data from adjacent vessel tracks. Chesapeake SonarWiz software was used to combine sonar data from each transect into a composite sonar mosaic.

\section{Interpretation of Magnetometer Data}

Low-frequency fluctuations in magnetic data caused, for example, by diurnal passage of the sun or by geologic gradients were removed, prior to contouring, using a filter algorithm. The algorithm treats short- 
term fluctuations, exceeding a selected amplitude threshold (typically 0.5 nanoTesla [ $\mathrm{nT}]$ ), as anomalous values. The result is a dataset in which abnormally high and low magnetic amplitudes (anomalies) are centered around zero (representing the ambient level). All amplitude shifts, smaller than the threshold value, are reduced to near zero and are treated as ambient background. This process removes low frequency data, leaving potentially significant anomalies intact, and allows a visual representation of anomaly polarity.

Magnetometer data illustrated in this report have been thinned to a 1-second interval between data points. Diurnally-corrected magnetometer data was contoured using Blue Marble's Global Mapper software (Version 17.2) at a 5-nT contour interval. Magnetic amplitudes between $+5 \mathrm{nT}$ and $-5 \mathrm{nT}$ are considered insignificant. Contour maps omit the 0-nT contour level to prevent a cluttered appearance. Positive amplitude is indicated by red contours, and negative amplitude is drawn as blue contours.

Most magnetic anomalies in marine environments are caused by relatively small pieces of ferromagnetic debris, which tend to concentrate near high-traffic areas, marine disposal areas, industrial developments, petroleum wells, and pipelines. Ferromagnetic debris far outnumbers shipwrecks, necessitating some means for distinguishing between the two when conducting archaeological assessments. Archaeologists have interpreted magnetic anomalies using a variety of criteria over the decades since marine geophysical surveys have been used for cultural resource investigations. Various factors, including amplitude, complexity and horizontal dimensions, have been considered important when trying to distinguish shipwreck anomalies from debris (non-shipwreck) anomalies. The interpretation method used by this author considers an additional factor, orientation, as an aid to segregating potential shipwreck anomalies from debris anomalies. Each of these factors is described in more detail below. The role of side-scan sonar in aiding interpretation is also considered.

The interpretative method described below is based primarily upon studies by Gearhart (2011b, 2016) that analyzed magnetic data from a large and diverse collection of anomaly sources, including 39 verified shipwrecks and many debris sources, with the goal of characterizing significant differences between shipwreck and debris anomalies. Shipwrecks included in this sample represent a broad spectrum of material compositions, construction styles, ages, and archaeological contexts. Their hulls include construction from wood, iron, steel, and concrete. Their propulsion systems range from sail to steamdriven paddlewheels and propellers, and from oil and diesel screws to towed or pushed barges. They range in age from the mid-16th to the mid-20th century. They have been found in diverse depositional environments including harbor entrances, surf zones, beaches, marsh, oyster reefs, open bay waters, and the Gulf of Mexico. And this assortment of watercraft found their way to the seafloor in various ways including stranding on beaches, foundering at sea, by fire, by explosions (both accidental and intentional), and by abandonment. Some were partially demolished or salvaged after wrecking. Others remain largely untouched since the day they sank. Yet despite their many differences, they share common characteristics, which form the basis for this interpretative method.

\section{Role of Sonar Imagery}

Anomaly sources exposed at the seafloor can be detected by side-scan sonar, which may, on occasion, be useful for determining their identity. For example, a straight, narrow, linear sonar target might be 
interpreted as a pipe. A pipe interpretation becomes more likely if that target is situated along the central axis of a magnetic dipole. On the other hand, if that same sonar target is not associated with a magnetic anomaly, one might interpret, instead, a tree or anchor scour. More often than not, sonar targets are unreliable indicators of magnetic source identity, but sonar occasionally provides unambiguous verification. Sonar also can aid magnetic interpretations because of what it does not show. For example, a magnetic anomaly without a corresponding sonar target, in saline, Texas coastal waters, is not likely associated with a shipwreck having either a metallic hull or a machine-powered propulsion system, except in areas of high sediment accretion.

Shipwrecks with metal hulls are usually exposed on the seafloor, thus tend to be fairly obvious on a sonar image. Gearhart (2011a) reported that 100 percent of shipwrecks discovered by BOEM-regulated geophysical surveys in shallow, Gulf of Mexico waters (less than $600 \mathrm{ft}$ deep) appear on side-scan sonar imagery $(n=74)$. About one third of that number are confirmed to have metal hulls. The rest are presumed to be metallic, simply because their ship-shaped structures are preserved in the water column. By comparison, only 7 wood-hulled wrecks were known to BOEM from the same area up to that time, but none of those were discovered by geophysical surveys, despite the fact that wood-hulled wrecks in the U.S., pre-dating World War II, are 13 times more abundant than metal-hulled wrecks (Gearhart 2011a). Wrecks of wood-hulled sailing ships, in Texas bays and adjacent coastal waters, are usually buried, thus they typically have no sonar target. Shipwrecks with wooden hulls and machine-powered propulsion systems might appear on sonar or might not. Lower portions of the wooden hull itself would tend to bury, but steam machinery is large and may remain exposed above the seafloor. Gas- and diesel-powered machinery tends to be smaller thus might be more easily buried than steam machinery.

\section{Amplitude}

Anomaly amplitude depends greatly upon the mass of the source and its distance from the magnetometer sensor. Small sources can produce large amplitude when measured at close range. Shipwreck anomalies from Gearhart (2011b) have average peak-to-peak amplitudes of 270 nT (range: 191-376 nT) for woodhulled sailing vessels (n=7); 5,020 nT (range: 663-15,247 nT) for wood-hulled, machine-powered vessels $(n=7)$; and 10,386 nT (range: 688-36,050 nT) for iron/steel-hulled vessels ( $n=12$ ). Anomalies from verified, wood-hulled sailing vessels in Gearhart (2011b) have lower peak-to-peak amplitude than anomalies associated with either machine-powered or iron/steel-hulled vessels; however, amplitudes from machine-powered and iron/steel-hulled vessels overlap one another. Magnetic debris can produce amplitudes virtually anywhere within the range of shipwreck anomalies, thus amplitude, alone, is of little use for differentiating shipwrecks from debris. Nevertheless, amplitude may aid in anomaly interpretation when considered in combination with other factors. For example, a buried anomaly source with amplitude greatly exceeding the range of verified, wood-hulled shipwrecks might be more likely caused by debris, since high-amplitude shipwreck anomalies, those with iron/steel hulls or machinery, are more likely exposed on the seafloor.

\section{Complexity}

Archaeologists frequently have described shipwreck anomalies as appearing "multicomponent" or "complex", while anomalies having simple, monopolar or dipolar shapes often were attributed to debris. Garrison, et al. (1989: II, 223) summarized several common methods for prioritizing anomalies with a focus 
on complexity. Shipwreck anomalies were characterized as having: multiple peaks of differing magnitudes spread over an area greater than 10,000 square meters (2.5 acres); gentle gradients; and a linear association with anomalies on adjacent transects. A typical debris anomaly was characterized as having a single peak covering an area of less than 10,000 square meters, a steep gradient, and no alignment of anomalies on adjacent lines.

Some early observations of complexity in wreck anomalies pre-dated computer contouring software. One or more peaks were observed on each transect crossing a single anomaly, but the spatial relationships between those peaks were not apparent. This problem was compounded by the lower accuracy of positioning systems prior to GPS. Thus, even a simple dipole might appear more complex than it really was. Earlier magnetometer technology also might have contributed to the perception of complexity. Proton precession systems tended to produce false noise spikes in the presence of high magnetic gradients, which could be interpreted as complex patterns of amplitude peaks where none existed.

The collection of 39 anomalies from verified shipwrecks reported by Gearhart (2011b, 2016) indicate, contrary to earlier models, that shipwreck anomalies (in mid-northern latitudes) tend to be dominated by a single main dipole, oriented approximately in line with magnetic north (Figure 5, for example; also see "Orientation" below). In fact, most debris anomalies also tend toward simple, dipolar shapes, while some shipwreck anomalies have more than two amplitude peaks. The concept of complexity is insufficient, by itself, to differentiate shipwrecks from debris anomalies; although, this fact does not lessen the need to correct any remaining misconceptions that shipwreck anomalies are typically complex and debris anomalies are not. The truth is more complicated than that simple dichotomy.

Many wreck anomalies also have secondary amplitude peaks, in addition to their main, north-southaligned dipole. Secondary peaks typically have lower amplitude than the main dipole and cover a smaller area than the main dipole peaks in all examples known to this author. Secondary peaks can be caused in two ways. The combined mass of the wreck either induces secondary peaks, or they are directly associated with individual ferromagnetic sources in a debris field.

Secondary peaks can be induced by the magnetic field lines emanating from wreckage. In mid-northern latitudes, a smaller peak sometimes occurs immediately north or south of, and in line with, the main dipole (e.g., peaks labelled " $A$ " in Figures 6, 7, and 8). Amplitude peaks of this nature are not necessarily located over an anomaly source and may not indicate the presence of widely-scattered wreckage. Rather they seem to be induced by a source of relatively high mass, such as a ferrous hull. In such cases, magnetic lines-of-force can loop so far to the north and/or south of a source that, respectively, they reinforce or diminish (i.e., are anomalous to) earth's field (Figure 7). The result is a small positive peak to the north and, occasionally, a smaller negative peak to the south of the main dipole. They will always have polarity opposite the adjoining peak of the main dipole. Such peaks are fairly symmetrical about an anomaly's north-south axis and will not overlap its main dipole. The inflection point between an induced secondary peak and the main dipole occurs where the anomaly's lines of magnetic force are perpendicular to earth's lines of force. 

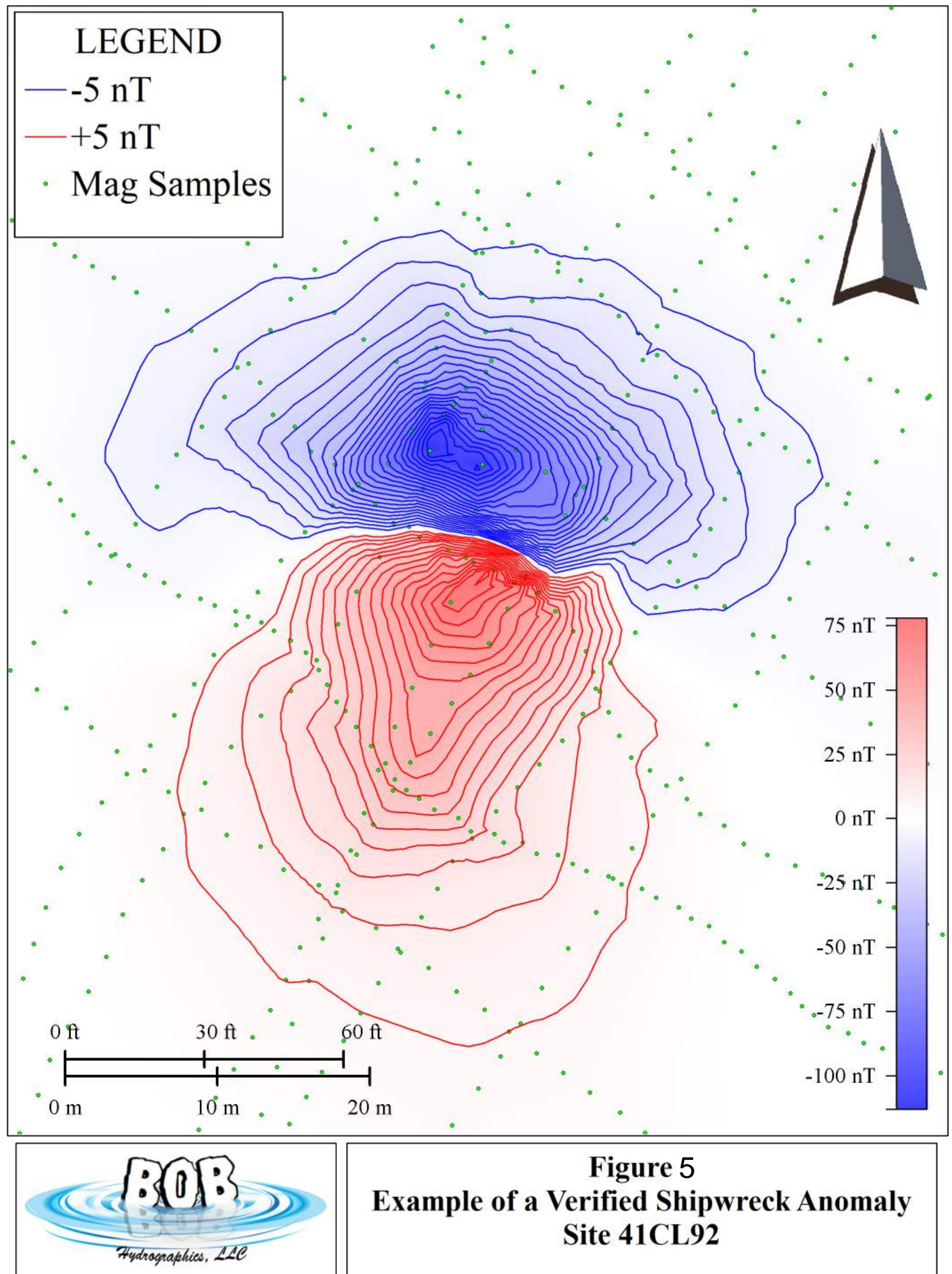

Figure 5

Example of a Verified Shipwreck Anomaly Site 41CL92 
Other secondary peaks may be directly caused by relatively large, individual magnetic sources within or near a hull or debris field. If such a mass is sufficiently large, its anomaly might not be completely cancelled by neighboring sources, allowing it to stand out. A similar effect may be observed if a magnetometer passes sufficiently close to a complex source, such as a shipwreck, so that some large-mass sources, are individually expressed against the background of the main dipole field. Such debris-centric, secondary peaks should have fairly random orientations and positions, with respect to the main dipole, since they are directly caused by randomly-positioned objects within a debris field. They may overlie and disrupt the symmetry of the primary north-south dipole (e.g., peaks labelled "B" in Figures 6 and 8).

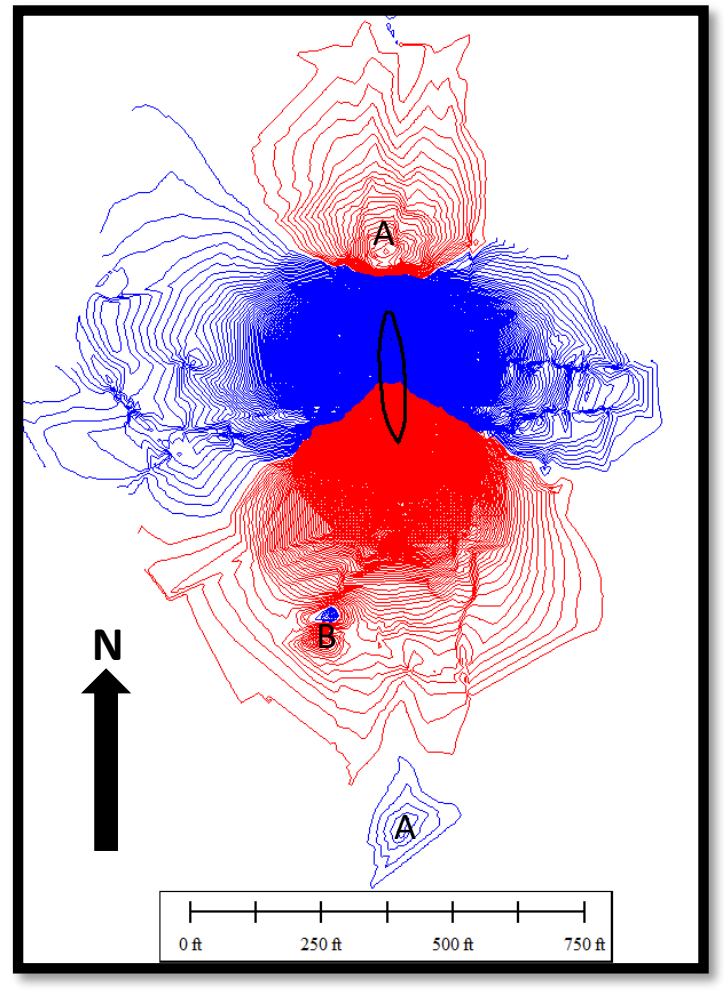

Figure 6: City of Waco Anomaly (iron hull) 5-nT contour interval

\section{Horizontal Dimensions}

Anomaly width, or duration as preferred by some, is a common and valid measure used by archaeologists for discriminating potential shipwreck anomalies from those believed more likely caused by debris. For example, Linden and Pearson (2014) would consider an anomaly significant if it has amplitude of at least $50 \mathrm{nT}$ and a width of $65 \mathrm{ft}$ or more. The horizontal dimensions of shipwreck and debris anomalies overlap considerably, especially when considering wrecks with wooden hulls, thus width alone is not particularly useful for discriminating between the two. There is a 15 -fold difference in width between the smallest wood-hulled sailing ship and the largest steel tanker, so large wrecks tend to be obvious. Unfortunately, small, wooden watercraft, even many steamboats, tend to have anomalies no wider than many debris anomalies.

Small shipwreck anomalies cannot be distinguished from debris anomalies based on size alone. All wooden-sailingship anomalies and all but one wooden-steamboat anomaly known to this author are smaller than 10,000 square meters, Garrison, et al.'s (1989: II, 223) minimum suggested size for typical shipwreck anomalies. Site 41CL92 (Figure 5), for example, covers an area of only 1,580 square meters ( 0.4 acres) out to the 5 -nT contour. Small, wooden, and generally historic, shipwrecks are the most difficult sites to detect precisely because their anomalies overlap in size with many debris anomalies.

The smallest wreck, although not the smallest anomaly, in Gearhart's anomaly dataset, Mag-13 (Figure 9), is a wooden hull buried 2-10 ft below the seafloor. The hull measures roughly $35 \times 13 \mathrm{ft}$, based on diver probes (Gearhart 2016). The Mag-13 anomaly measures $197 \times 164 \mathrm{ft}(60 \times 50 \mathrm{~m})$ across. Site 41CL92 (Figure 5), although having larger site dimensions, has the smallest verified wreck anomaly known to this author, measuring $176 \times 155 \mathrm{ft}(53.6 \times 47.2 \mathrm{~m})$ to the 5-nT contour. Divers identified Site 41CL92 as an early 19th-century sailing vessel containing a large collection of concreted artifacts, iron bar stock, and pig 
iron ballast but with no hull remaining (Borgens 2004). Its debris field measures $52 \times 23 \mathrm{ft}(15.9 \times 7 \mathrm{~m})$ across.

The 41CL92 anomaly is smaller than the Mag-13 anomaly, even though the 41CL92 site dimensions are larger. Its smaller magnetic footprint might be due to its disarticulated nature, whereas the Mag-13 site appears to have an intact hull. The higher entropy of a disarticulated wreck, in theory, should result in a lower peak amplitude and a smaller magnetic footprint, all other things being equal, than if the same wreck were an intact hull. Unfortunately, the original hull dimensions of 41CL92 are unknown. Although it represents the smallest anomaly known to date for a disarticulated wooden wreck, smaller examples likely exist. A realistic lower limit for the dimensions of a significant anomaly remains open for debate. In the meanwhile, a working estimate is suggested below.

The smallest likely size of historic commercial watercraft in the Gulf Coast trade can be determined through research. For example, the average size of wooden sailing vessels registered in the Port of New

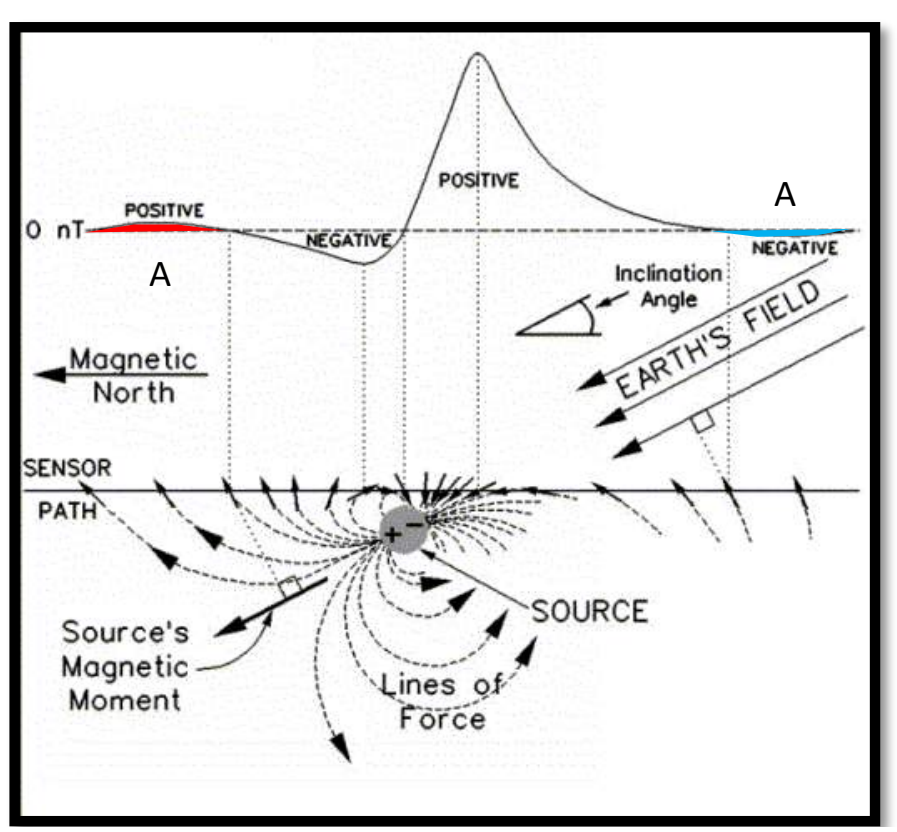

Figure 7: Induced Magnetic Anomaly Orleans during the period 1804-1820 was 71 x $21 \mathrm{ft}(21.6 \times 6.4 \mathrm{~m})$ (based on Works Progress Administration [1941] as summarized in Ford et al. 2008: 54-71). The smallest vessel registered in New Orleans during the same period was the schooner Tickler, which measured only $29 \times 10 \mathrm{ft}$ (8.8 x $3.0 \mathrm{~m}$ ) (Works Progress Administration 1941: $127)$, roughly 81 percent the size of the Mag13 hull.

It seems reasonable, based on comparison with the Mag-13 wreck, that an intact wooden vessel as small as Tickler might have an anomaly measuring as much as 81 percent smaller than the Mag-13 anomaly, that is to say $160 \times 133 \mathrm{ft}(48.8 \times 40.5 \mathrm{~m})$ across, or an average diameter of $147 \mathrm{ft}$. The 41CL92 anomaly, the smallest verified wreck anomaly known to this author, measures 92 percent smaller than the Mag-13 wreck anomaly, possibly because the site is disarticulated. To be conservative, the hypothetical anomaly size for Tickler, likewise, has been adjusted downward by 92 percent, yielding an estimate of $147 \times 122 \mathrm{ft}(44.8 \times 37.2 \mathrm{~m})$, or an average diameter of $135 \mathrm{ft}(41.1 \mathrm{~m})$. This author, therefore, will consider dipoles potentially significant if they align with magnetic north and have a minimum horizontal dimension of at least $135 \mathrm{ft}(41.1 \mathrm{~m})$, which is 81 percent smaller than the 41CL92 anomaly. 


\section{Orientation}

Shipwreck anomalies (e.g., Figures 5, 6, 7, and 8) consistently share a common orientation with respect to earth's magnetic field, despite the great diversity of wrecks described above. All wreck anomalies observed by this author, to date, are oriented with their primary negative pole situated north of their positive pole. The local direction of magnetic north agrees, on average, within +/- 10 degrees of the dipole alignment for 29 verified wreck anomalies, reported in Gearhart (2011b). The maximum reported difference between dipole alignment and magnetic north direction was 26 degrees. A similar orientation is expected of all wrecks, as well as all other complex anomaly sources, in mid-latitudes of the northern hemisphere; however, the orientation of anomalies over simple debris sources is not limited.

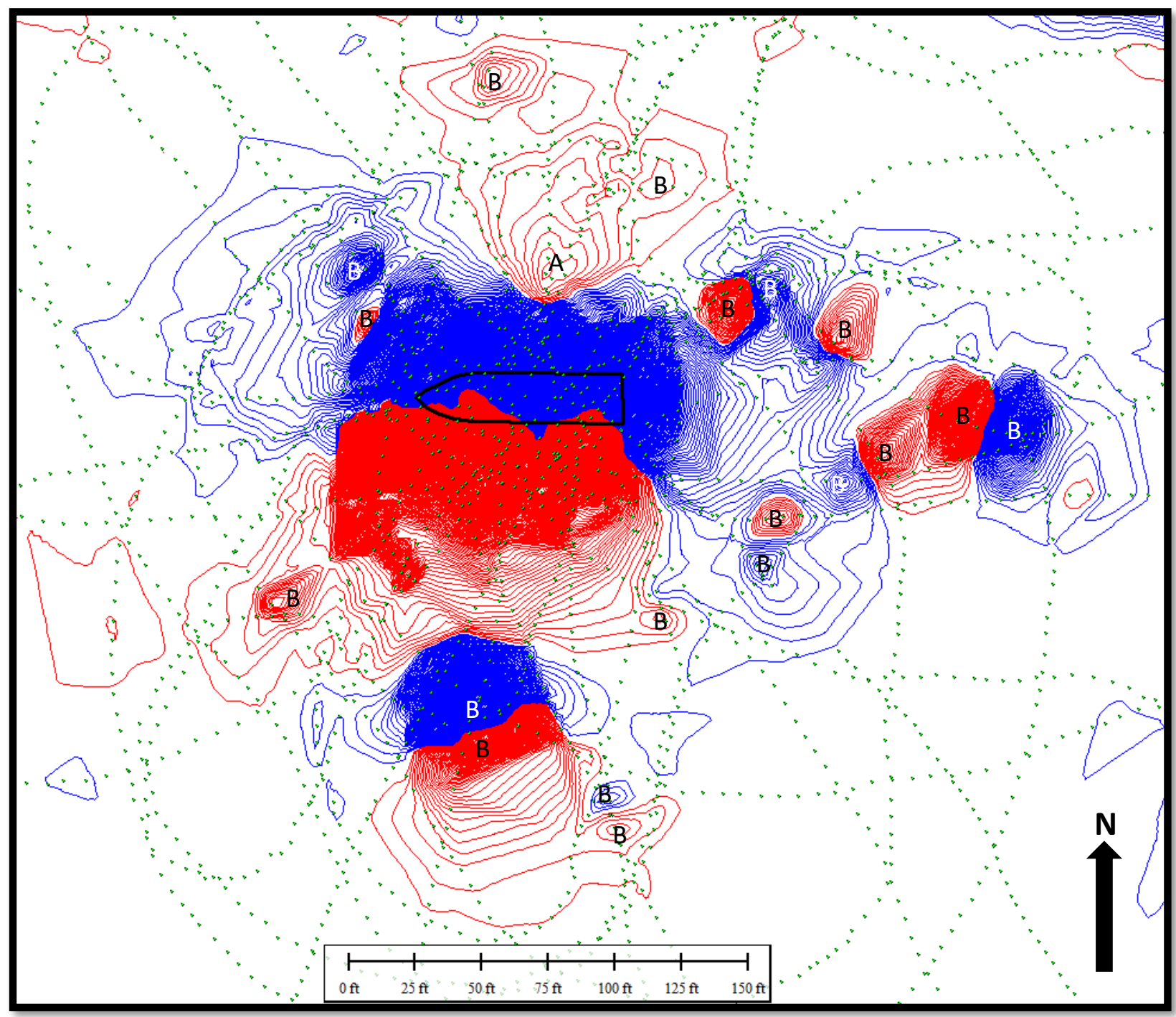

Figure 8: 41CH372 Anomaly (steel hull), 5-nT contour interval

Shipwrecks, and other complex sources, have anomalies closely aligned to the direction of magnetic north. This phenomenon is believed due to the random orientations of many individual magnetic components that make up each complex source, including shipwrecks. The magnetic field of each component interacts 
with that of its neighbors. The overlapping portions of fields that oppose one another in direction tend to cancel, while lines of force that run in the same general direction reinforce each other. Since a small portion of each field is aligned with (induced by) earth's local field, the net result of all these interactions is that more reinforcement occurs in the direction of magnetic north than in any other direction, resulting in a north-aligned anomaly. A simple debris source, on the other hand, is a solitary object on the seabed. By definition, there are no nearby sources affecting its magnetic field, thus the alignment of its anomaly is determined not by earth's magnetic field direction but by the object's orientation on the seabed. Hence debris anomalies can be oriented along any point of the compass.

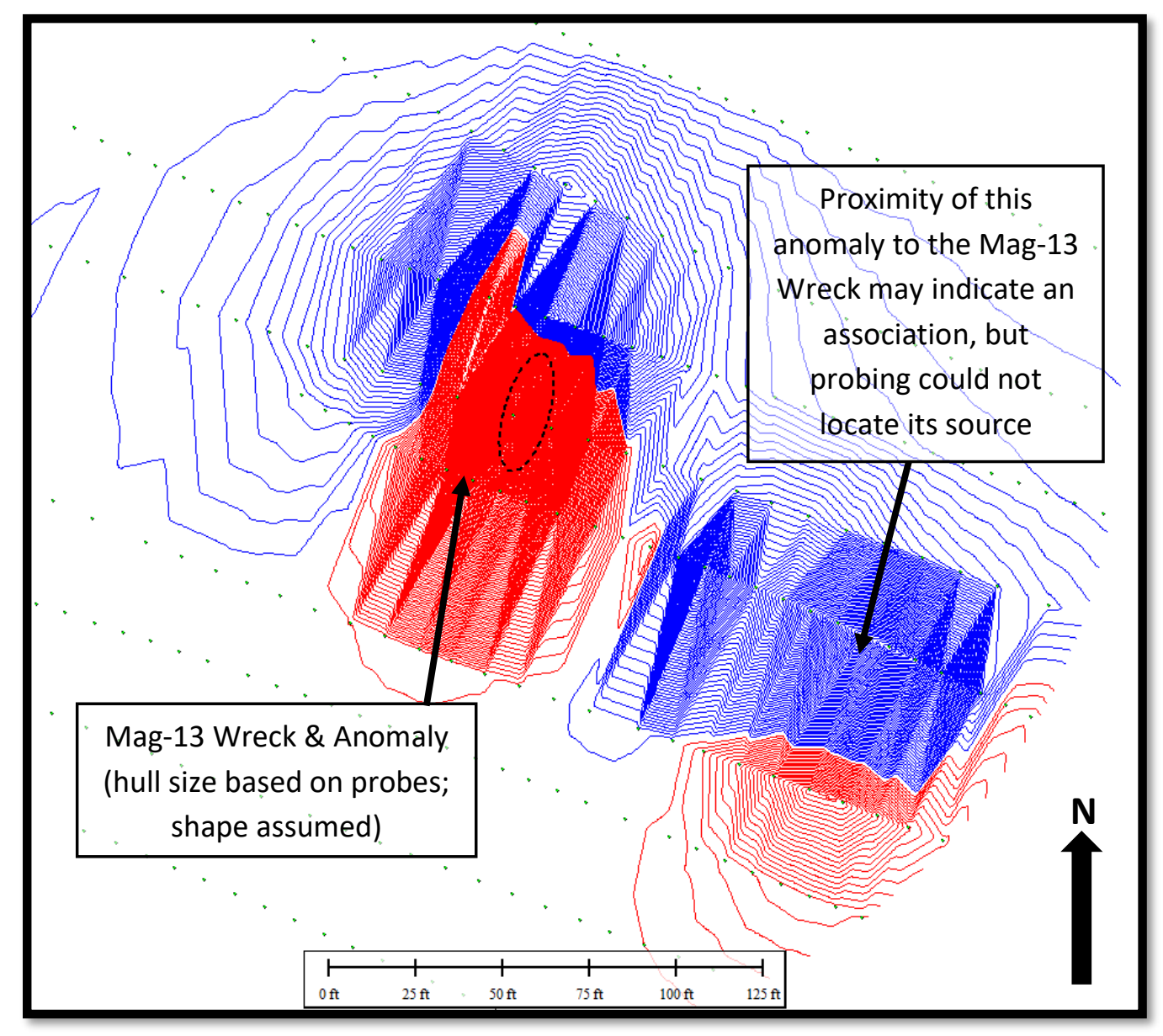

Figure 9: Mag-13 Wreck Anomaly (wooden hull)

5-nT contour interval (Gearhart 2016: 46)

Orientation can differentiate magnetic anomalies caused by most simple debris sources from anomalies caused by complex sources, including shipwrecks, and has potential to eliminate close to 80 percent of debris anomalies from further archaeological concern. Roughly 20 percent of simple debris sources have northerly orientations like those observed over complex sources. Absent a sonar target, there is no reliable method known, short of physically probing an anomaly, to differentiate that 20 percent of debris having northerly orientations from complex sources, including potential buried shipwrecks. 
Anomalies can be eliminated from consideration as potential shipwrecks by demonstrating that their orientations differ substantially from the direction of magnetic north. It seems unlikely that a shipwreck could have a magnetic anomaly that is not aligned closely with magnetic north, as this would require a large percentage of the wreck's many ferromagnetic components, by chance, to have the same magnetic moment. On the other hand, the anomaly of a simple debris source should align with earth's magnetic field only when its magnetic moment, as determined by the source's orientation on the seafloor, closely aligns with magnetic north.

The interpretation of magnetic anomalies based on orientation requires comparing unidentified magnetic anomalies, contoured at a 5-nT interval, to the anomaly of a small, verified wreck anomaly, such as $41 C L 92$, shown in Figure 5. One must ensure that the reference anomaly is contoured, oriented and scaled using the same parameters as the survey data to which it is compared. Anomalies having a polar orientation similar to that of 41CL92 should be considered possible shipwrecks unless contradicted by other information, such as reliable evidence of an abandoned petroleum well nearby, as anomalies over steel well casings often closely resemble shipwreck anomalies. Information regarding petroleum infrastructure is available on the TxRRC Public GIS Viewer to rule out association with wells.

\section{Significance Criteria}

BOB's minimum criteria for archaeological assessment of magnetic anomalies (in mid-latitudes of the northern hemisphere) requires that a significant anomaly, surveyed at 20-m intervals, be consistent with the following conditions: a) it must have at least one dipole, oriented with its negative pole north of its positive pole; b) it should be at least $135 \mathrm{ft}$ ( $41.1 \mathrm{~m}$ ) across (to the +/- 5-nT contour); and c) it should appear on a minimum of 2 transects. If survey lines are spaced at 10-m intervals, a significant anomaly should meet all of the above conditions and d) should appear on at least 4 transects. An anomaly's shape usually is not obvious if data is from a single survey transect; thus, additional criteria have been designed to avoid missing significant targets. If survey lines are spaced at greater than $20-\mathrm{m}$ intervals, a significant anomaly e) may be limited to a single transect; and f) may appear as a monopole. Exceptions may be made in either direction, at the Principal Investigator's discretion, based on mitigating circumstances or professional judgment. Resemblance to verified shipwreck anomalies, including the 39 reported by Gearhart (2011b, 2016), should be an important factor in such judgments when close-order survey has been conducted.

\section{Results}

Sonar and magnetometer data are illustrated for the entire survey in Appendices A and B, respectively. The archaeology APE is overlaid in both appendices as a yellow polygon inset $50 \mathrm{~m}$ from the perimeter of the main survey corridors. The petroleum-industry channels surveyed on the eastern and western ends of the project have been dredged thus are not considered part of the archaeology APE. These channels will be utilized for routing the pipe through shoal areas of protected seagrass beds. Seagrasses will be avoided by horizontal directional drilling in other protected areas as indicated by polygons shaded yellow in Figure 1. 


\section{Side-Scan Sonar}

Side-scan sonar data is illustrated as a mosaic in Appendix A. Positions of magnetic anomaly avoidance buffers are overlaid on the mosaic for reference. Hard targets and areas of seagrass or shellfish beds would appear as darker areas on the sonar mosaic. Area resembling seagrass are visible on sonar images where the water becomes shallow at both ends of the APE corridors. Sonar targets were primarily biological in origin. No significant sonar targets of an archaeological nature were discovered by this survey.

\section{Magnetometer}

Magnetic anomalies greater than $+/-5 \mathrm{nT}$ are illustrated as contours in Appendix B. Survey transects are illustrated as a green dotted path superimposed on pre-planned lines. Information regarding petroleum infrastructure was obtained from the Railroad Commission of Texas' Public GIS Viewer and is overlaid on magnetometer results in Appendix B.

Four anomalies, designated Anomalies 1-4, meet the significance criteria described in the previous section. Three of those targets, Anomalies 1-3 (Appendix B, sheets 2 and 3), are interpreted as potential historic shipwrecks. Anomaly 4 (Appendix B, Sheet 2 ) is associated with an abandoned petroleum well. Enlarged views of anomalies 1, 2 and 3 are illustrated in figures 10, 11 and 12, respectively, alongside the Site 41CL92 reference anomaly (see Figure 5), the smallest verified wreck anomaly known to this author. The anomalies are shown, in each case, at the same scale and orientation as the reference anomaly.

\section{Recommendations}

Three geophysical targets, Anomalies 1, 2 and 3, are recommended for avoidance. Details concerning these targets are provided in Appendix C. Each of these anomalies meets the significance criteria described in this report for targets potentially associated with shipwrecks. Should any of these three targets prove to be associated with a historic shipwreck, they may qualify for State Antiquities Landmark status or for NRHP eligibility. BOB recommends avoidance of Anomalies 1, 2 and 3 by $50 \mathrm{~m}(164 \mathrm{ft}$ ) beyond their 5-nT magnetic contours as mandated by THC guidelines.

Portions of the APE located outside of anomaly avoidance zones are recommended for cultural resource clearance. Likewise, petroleum industry channels, located outside of the archaeology APE, are recommended for clearance, since those channels have been disturbed by dredging. Avoidance buffers are mandated by The Texas Administrative Code, Title 13, Part 2, Chapter 26. The buffer for inshore waters, less than 3 miles from the beach, is set at $50 \mathrm{~m}(164 \mathrm{ft})$ beyond significant target boundaries and around the perimeter of project-related seafloor disturbances. Disturbance of the seafloor must be avoided within this mandated 50-m (164-ft) buffer around the APE as illustrated in Appendices A and B. If shipwreck remains, or other potentially historic materials, are discovered anywhere in the survey area during construction, work should be halted within $50 \mathrm{~m}$ (164 ft) of the find until the THC can provide guidance concerning the discovery. 


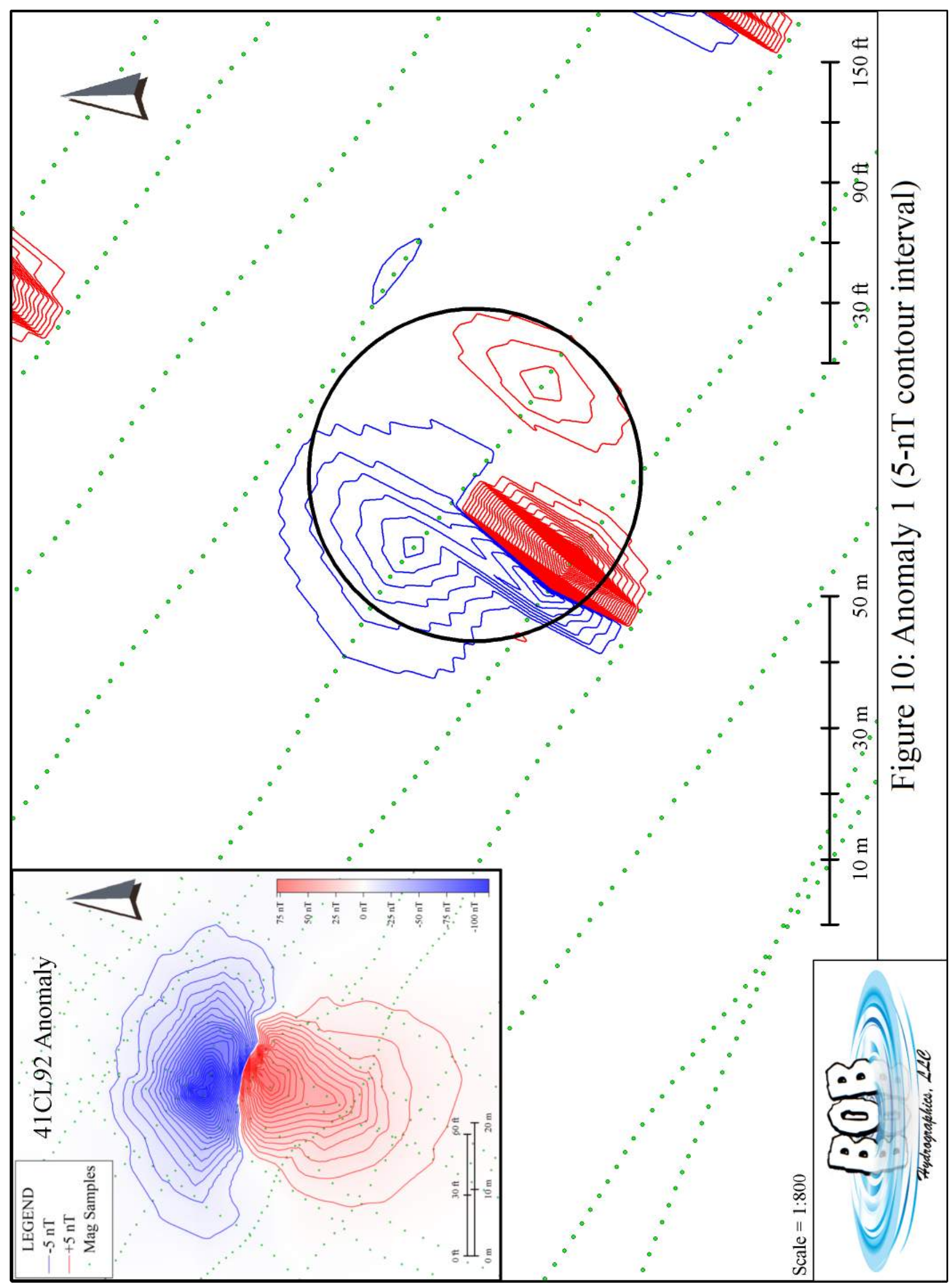




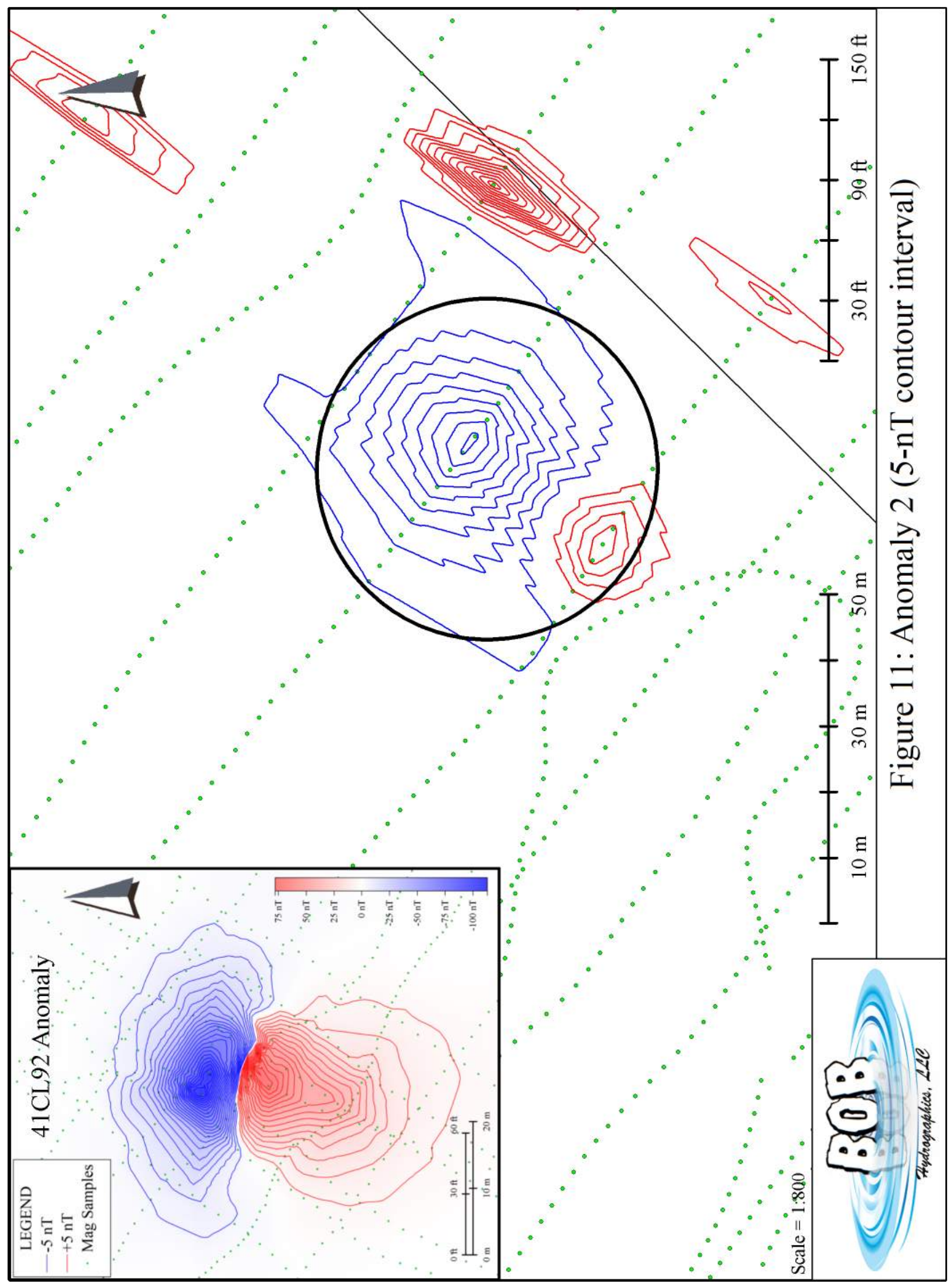




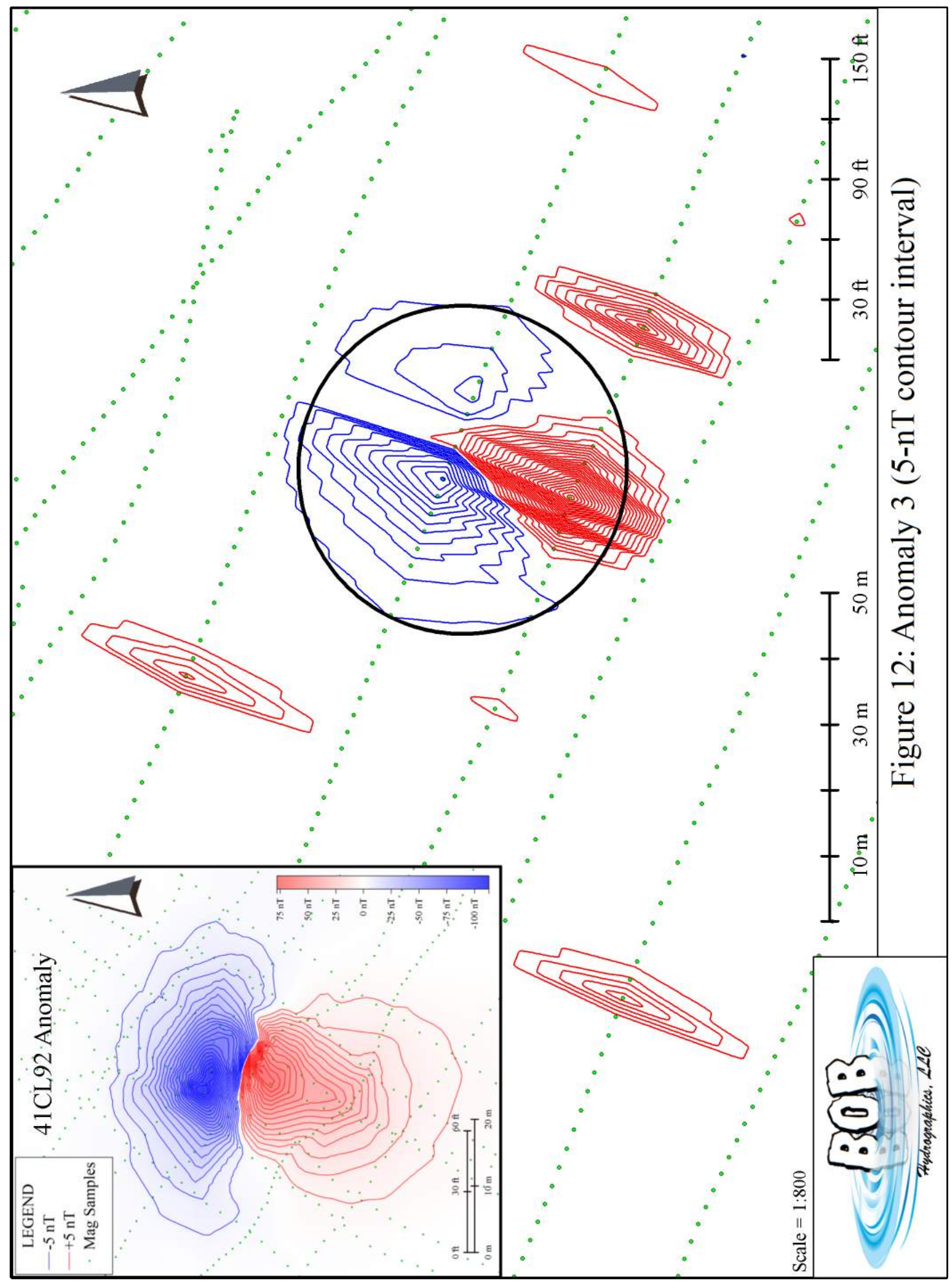




\section{References Cited}

Alperin, Lynn. 1977. Custodians of the Coast: History of the United States Army Engineers at Galveston. Galveston District, United States Army Corps of Engineers.

Bolton, Herbert Eugene. 1915. Texas in the Middle Eighteenth Century: Studies in Spanish Colonial History and Administration. University of California Publications in History, Volume III. University of California Press, Berkeley.

Borgens, Amy. 2004. Analysis of the Pass Cavallo Wreck Assemblage, Matagorda Bay, Texas. Master's thesis, Texas A\&M University, College Station.

Cabeza de Vaca, Álvar Núñez. 2013. Chronicle of the Narváez Expedition, Translation of 'La Relacion', translated by David Frye, edited by Ilan Stavans. Norton Critical Edition.

Chipman, Donald E., and Harriett Denise Joseph. 2010. Spanish Texas 1519-1821, Revised Edition. University of Texas Press, Austin.

Covey, Cyclone. 1983. Cabeza de Vaca's Adventures in the Unknown Interior of America. University of New Mexico Press. Albuquerque.

Enright, Jeffrey, Jenna Watts, and Robert Gearhart. 2003. Marine Remote-Sensing Survey and Diving Assessment for Historic Properties Investigations, Corpus Christi Channel Improvements and La Quinta Ship Channel Extension, Corpus Christi Bay, Nueces County, Texas. Prepared for the U.S. Army Corps of Engineers, Galveston District. PBS\&J Document 020143. Austin.

Folsom, Charles J. 1842. Mexico in 1842: A Description of the Country, Its Natural and Political Features; with a Sketch of its History, Brought Down to the Present Year. Wiley and Putnam; Robinson, Pratt and Co. New York.

Ford, B., A. Borgens, W. Bryant, D. Marshall, P. Hitchcock, C. Arias and D. Hamilton. 2008. Archaeological excavation of the Mardi Gras Shipwreck (16GM01), Gulf of Mexico Continental Slope. OCS Report MMS 2008-037. U.S. Department of Interior, Minerals Management Service, Gulf of Mexico OCS Region, New Orleans.

Foster, Eugene, Ty Summerville, and Thomas Brown. 2006. The Texas Historic Overlay: A Geographic Information System of Historic Map Images for Planning Transportation Projects in Texas. PBS\&J Document 060206. Texas Department of Transportation, Environmental Affairs Division, Austin.

Garrison, E. G., C. P. Giammona, F. J. Kelly, A. R. Tripp and G. A. Wolff. 1989. Historic shipwrecks and magnetic anomalies of the northern Gulf of Mexico: Reevaluation of archaeological resource management zone 1. Volume II: technical narrative. OCS Study, MMS 89-0024. U.S. Department of the Interior, Minerals Management Service, Gulf of Mexico OCS Region.

Gearhart, Robert. 2011a. Wooden Shipwrecks of the Central and Western Gulf of Mexico. Paper presented at Offshore Technology Conference, Houston, Texas. 
Gearhart, Robert. 2011b. Archaeological Interpretation of Marine Magnetic Data, Chapter 4 in The Oxford Handbook of Maritime Archaeology, Alexis Catsambis, Ben Ford, and Donny L. Hamilton, editors, pp. 90-113. Oxford University Press, New York, New York.

Gearhart II, Robert. 2016. Marine Archaeological Survey of Proposed North Jetty Sand Search, Galveston County, Texas. Prepared for HDR Engineering, Inc. Surveying And Mapping, LLC, Austin, Texas.

Gearhart, Robert, John Neville, and Steven Hoyt. 1990. California, Oregon, and Washington Archaeological Resource Study, Volume IV: History. Prepared for Minerals Management Services, Pacific Region. OCS Study MMS 90-0090. Espey, Huston \& Associates, Inc., Austin, Texas.

Hamilton, Donny. 1999. Methods of Conserving Archaeological Material from Underwater Sites, Revision Number 1. Conservation Files: ANTH 605, Conservation of Cultural Resources I. Nautical Archaeology Program, Texas A\&M University, World Wide Web, http://nautarch.tamu.edu/CRL/conservation manual/ConservationManual.pdf, last accessed on 20 December 2018.

Hedrick, Layne. 2001. Remote-Sensing Investigation of Corpus Christi Bayou and the Morris and Cummings Cut in Red Fish Bay, Aransas and Nueces Counties, Texas. Prepared for Cabot Oil by PBS\&J, Austin.

Hedrick, Layne and Robert Gearhart. 2002. Remote-Sensing Investigation of Six Proposed Well Pads and Two Proposed Pipeline Routes in Corpus Christi Bay, Nueces County, Texas. Prepared for IBC Petroleum by PBS\&J, Austin.

Hoskins, Sara, Jenna Enright, and Robert Gearhart. 2006. Marine Remote- Sensing Survey for a Proposed Flow Line from Existing Platform 343-1 to Well St. 344-2, Corpus Christi Bay, Nueces County, Texas. Prepared Boss Exploration and Production Corporation by PBS\&J, Austin.

Hoyt, Steven D. 1990. National Register Assessment of the SS Mary, Port Aransas, Nueces County, Texas. Prepared for the U.S. Army Corps of Engineers, Galveston District. Espey, Huston \& Associates, Inc. Document 900311, Austin, Texas.

Hunt, Richard S., and Jesse F. Randel. 1839. Map of Texas compiled from Surveys on Record in the General Land Office of the Republic, to the Year 1839. Published by J.H. Colton. New York. Courtesy of Texas State Library and Archives Commission.

Huson, Hobart. 1935. El Copano, The Ancient Port of Bexar and La Bahía. Published by The Refugio Timely Remarks, Refugio, Texas.

James, Stephan and Michael Faught. 2008. Submerged Cultural Resources Remote Sensing Survey of Proposed Wellheads and Pipelines in State Lease Tract 345, Corpus Christi Bay, Nueces County, Texas. Prepared for Cinco Natural Resources Corporation by Panamerican Consultants, Inc., Memphis, Tennessee.

Kuehne, Cyril Mathew. 1973. Hurricane Junction: A History of Port Aransas. St. Mary's University, San Antonio. 
Linden, Sarah and Charles Pearson. 2014. Phase I Marine Cultural Resources Remote-Sensing Survey in Buffalo Bayou for the Proposed Kinder Morgan Export Terminal, Pasadena, Harris County, Texas. Coastal Environments, Inc. Corpus Christi, Texas.

Long, Christopher. 2010. Corpus Christi, TX, Handbook of Texas Online, accessed December 20, 2018, http://www.tshaonline.org/handbook/online/articles/hdc03.

Lugo-Fernandez, A., D.A. Ball, M. Gravois, C. Horrell, and J.B. Irion. 2007. Analysis of the Gulf of Mexico's Veracruz-Havanna Route of La Flota de la Nueva España. Journal of Maritime Archeology (2007) 2:24-47.

Marcy, R.B. 1855. Chart of Soundings Through the Different Channels in Aransas and Metagorda Bays as Taken in 1855 by Capt. R.B. Marcy, U.S.A. Courtesy of Texas General Land Office.

McDonald, David, and J. Barto Arnold III. 1979. Documentary Sources for the Wreck of the New Spain Fleet of 1554. Texas Antiquities Committee, Publication \#8. Austin.

McGowen, J.H., L.F. Brown, Jr., T.J. Evans, W.L. Fisher, and C.G. Groat. 1976. Environmental Geologic Atlas of the Texas Coastal Zone - Bay City-Freeport Area. Bureau of Economic Geology, The University of Texas at Austin.

United States Coast and Geodetic Survey. 1884. Coast Chart No. 209, Aransas Pass, Aransas and Copano Bays, Texas. Map image provided courtesy of The Center for American History, The University of Texas at Austin.

United States Coast and Geodetic Survey. 1887. Coast Chart No. 210, Aransas Pass and Corpus Christi Bay, Texas. Map image provided courtesy of The Center for American History, The University of Texas at Austin.

United States Department of the Treasury. 1906-1946. Annual List of Merchant Vessels of the United States. U.S. Government Printing Office, Washington, D.C.

Weddle, Robert S. 1985. Spanish Sea: The Gulf of Mexico in North American Discovery, 1500-1685. Texas A\&M University Press, College Station, Texas.

Weddle, Robert S. 1991. The French Thorn: Rival Explorers in the Spanish Sea, 1682-1762. Texas A\&M University Press, College Station, Texas.

Weise, Bonnie R., William A. White, L.F. Brown, and Walter K. Ferguson. 1980. Padre Island National Seashore: A Guide to the Geology, Natural Environments, and History of a Texas Barrier Island. Texas Bureau of Economic Ecology, Guidebook 17. Bureau of Economic Geology, The University of Texas, Austin.

Works Progress Administration. 1941. Ship Registers and Enrollments of New Orleans, Louisiana, Volume I (1804-1820). Prepared by the Survey of Federal Archives in Louisiana, Division of Community Service Programs. T.S. Hill Memorial Library, Louisiana State University, Baton Rouge. 
Appendix A: Side-Scan Sonar Mosaic (Not for Public Disclosure)

A-1 | P a g e 
Appendix B: Magnetic Contours (Not for Public Disclosure)

B-1 | P a g e 
Appendix C: Geophysical Targets Recommended for Avoidance (Not for Public Disclosure) 
Appendix D: Texas Antiquities Permit 8645 and THC Concurrence Letter

D-1 | P a g e 


\section{TEXAS HISTORICAL COMMISSION \\ real places telling real stories}

Monday, November 12, 2018

Robert Gearhart

BOB Hydrographics, LLC

1315 Fall Creek Loop

Cedar Park, TX 78613-5820

Re: $\quad$ Project review under the Antiquities Code of Texas

Final Report: Axis Midstream Redfish Bay Pipeline Project

Texas Antiquities Permit \# 8645

Dear Colleague:

Thank you for your Antiquities Permit Application for the above referenced project. This letter presents the final copy of the permit from the Executive Director of the Texas Historical Commission (THC), the state agency responsible for administering the Antiquities Code of Texas.

Please keep this copy for your records. The Antiquities Permit investigations requires the production and submittal of one printed copy of the final report, a completed abstract form submitted via our online system, two copies of the tagged PDF final report on CD (one with site location information \& one without), and verification that any artifacts recovered and records produced during the investigations are curated at the repository listed in the permit. The abstract form maybe submitted via the THC website (www.thc.state.tx.us) or use url:

http://xapps.thc.state.tx.us/Abstract/login.aspx

Additionally, you must send the THC shapefiles showing the boundaries of the project area and the areas actually surveyed via email to archeological_projects@thc.texas.gov.

If you have any questions concerning this permit or if we can be of further assistance, please contact the reviewer, Amy Borgens at (512) 463-9505.

Sincerely,

Nick Barrett:

Antiquities Permit Coordinator

(512) 463-1858

Enclosures

Cc :Texas General Land Office Axis Midstreem Holdings, LLC

\section{D-2 | Page}




\section{State of Texas \\ TEXAS ANTIQUITIES COMMITTEE}

ARCHEOLOGY PERMIT \# 8645

This permit is issued by the Texas Historical Commission, hereafter referred to as the Commission, represented herein by and through its duly authorized and empowered representatives. The

Commission, under authority of the Texas Natural Resources Code, Title 9, Chapter 191, and subject to the conditions hereinafter set forth, grants this permit for:

\section{Underwater Excavations}

To be performed on a potential or designated landmark or other public land known as:

Title: $\quad$ Axis Midstream Redfish Bay Pipeline Project

County: Nueces

Location: Redfish Bay between mainland and Harbor Island

Owned or Controlled by: (hereafter known as the Permittee):

Texas General Land Office

1700 N. Congress Ave. Ste 935

Austin TX 78701

Sponsored by (hereafter known as the Sponsor

Axis Midstreem Holdings, LLC

5005 Riverway Dr., Suite 110

Houston TX 77056

The Principal Investigator/Investigation Firm representing the Owner or Sponsor is:

Robert Gearhart

BOB Hydrographics, LLC

1315 Fall Creek Loop

Cedar Park, TX 78613-5820

This permit is to be in effect for a period of:

1 Years and 0 Months

and Will Expire on:

11/12/2019

During the preservation, analysis, and preparation of a final report or until further notice by the

Commission, artifacts, field notes, and other data gathered during the investigation will be kept temporarily at:

BOB Hydrographics, LLC

Upon completion of the final permit report, the same artifacts, field notes, and other data will be placed in a permanent curatorial repository at:

Texas Archeological Research Lab.

Scope of Work under this permit shall consist of:

Underwater survey, see attached scope and design for more details.

D-3 | Page 
This permit is granted on the following terms and conditions:

1) This project must be carried out in such a manner that the maximum amount of historic, scientific, archeological, and educational information will be recovered and preserved and must include the scientific, techniques for recovery, recording, preservation and analysis commonly used in archeological investigations. All survey level investigations must follow the state survey standards and the THC survey requirements established with the projects sponsor(s).

2) The Principal Investigator/Investigation Firm, serving for the Owner/Permittee and/or the Project Sponsor, is responsible for insuring that specimens, samples, artifacts, materials and records that are collected as a result of this permit are appropriately cleaned, and cataloged for curation. These tasks will be accomplished at no charge to the Commission, and all specimens, artifacts, materials, samples, and original field notes, maps, drawings, and photographs resulting from the investigations remain the property of the State of Texas, or its political subdivision, and must be curated at a certified repository. Verification of curation by the repository is also required, and duplicate copies of any requested records shall be furmished to the Commission before any permit will be considered complete.

3) The Principal Investigator/Investigation Firm serving for the Owner/Permittee, and/or the Project Sponsor is responsible for the publication of results of the investigations in a thorough technical report containing relevant descriptions, maps, documents, drawings, and photographs. A draft copy of the report must be submitted to the Commission for review and approval. Any changes to the draft report requested by the Commission must be made or addressed in the report, or under separate written response to the Commission. Once a draft has been approved by the Commission, one (1) printed, unbound copy of the final report containing at least one map with the plotted location of any and all sites recorded and two copies of the report in tagged PDF format on an archival quality CD or DVD shall be furmished to the commission. One copy must include the plotted location of any and all sites recorded and the other should not include the site location data. A paper copy and an electronic copy of the completed Abstracts in Texas Contract Archeology Summary Form must also be submitted with the final report to the Commission. (Printed copies of forms are available from the Commission or also online at www.thc.state.tx.us.)

4) If the Owner/Permittee, Project Sponsor or Principal Investigator/Investigation Firm fails to comply with any of the Commission's Rules of Practice and Procedure or with any of the specific terms of this permit, or fails to properly conduct or complete this project within the allotted time, the permit will fall into default status. A notification of Default status shall be sent to the Principal Investigator/Investigation Firm, and the Principal Investigator will not be eligible to be issued any new permits until such time that the conditions of this permit are complete or, if applicable, extended.

5) The Owner/Permittee, Project Sponsor, and Principal Investigator/Investigation Firm, in the conduct of the activities hereby authorizes, must comply with all laws, ordinances and regulations of the State of Texas and of its political subdivisions including, but not limited to, the Antiquities Code of Texas; they must conduct the investigation in such a manner as to afford protection to the rights of any and all lessees or easement holders or other persons having an interest in the property and they must return the property to its original condition insofar as possible, to leave it in a state which will not create hazard to life nor contribute to the deterioration of the site or adjacent lands by natural forces.

6) Any duly authorized and empowered representative of the Commission may, at any time, visit the site to inspect the fieldwork as well as the field records, materials, and specimens being recovered.

7) For reasons of site security associated with historical resources, the Project Sponsor (if not the Owner/Permittee), Principal Investigator, Owner, and Investigation Firm shall not issue any press releases, or divulge to the news media, either directly or indirectly, information regarding the specific location of, or other information that might endanger those resources, or their associated artifacts without first consulting with the Commission, and the State agency or political subdivision of the State that owns or controls the land where the resource has been discovered.

8) This permit may not be assigned by the Principal Investigator/Investigation Firm, Owner/Permittee, or Project Sponsor in whole, or in part to any other individual, organization, or corporation not specifically mentioned in this permit without the written consent of the Commission. 9) Hold Harmless: The Owner/Permittee hereby expressly releases the State and agrees that Owner/Permittee will hold harmless, indemnify, and defend (including reasonable attomey's fees and cost of litigation) the State, its officers, agents, and employees in their official and/or individual capacities from every liability, loss, or claim for damages to persons or property, direct or indirect of whatsoever nature arising out of, or in any way connected with, any of the activities covered under this permit. The provisions of this paragraph are solely for the benefit of the State and the Texas Historical Commission and are not intended to create or grant any rights, contractual or otherwise, to any other person or entity.

10) Addendum: The Owner/Permittee, Project Sponsor and Principal Investigator/Investigation Firm must abide by any addenda hereto attached.

Upon a finding that it is in the best interest of the State, this permit is issued on 11/12/2018.
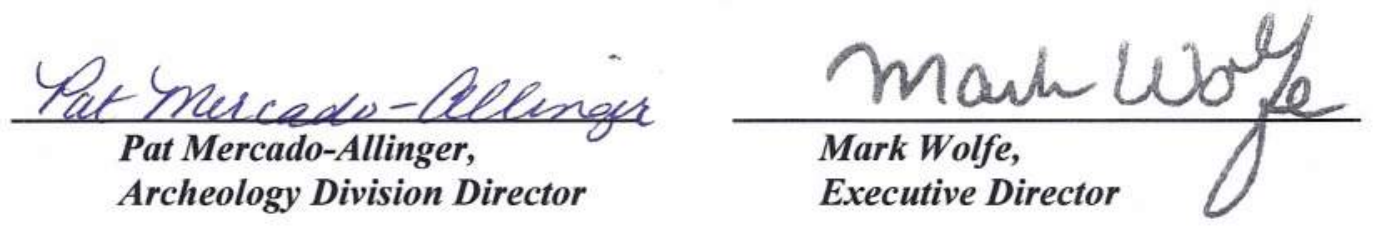
December 21, 2018

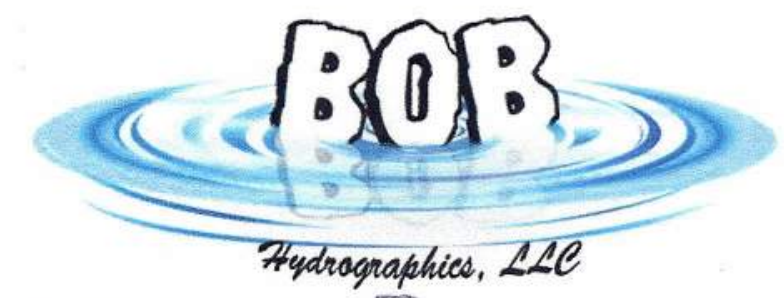

Amy Borgens

State Marine Archaeologist

RECEIVED

dith 1 b 2013

Texas Historical Commission

108 West 16 th Street

Austin, Texas 78711

RE: Antiquities Permit 8645, Redfish Bay Pipeline Project, Nueces County

Dear Ms. Borgens:

BOB Hydrographics, LLC (BOB) is pleased to deliver a marine archaeology survey report (printed draft) for the above-referenced project. I would appreciate your review of this report, on behalf of my client, Project Consulting Services, Inc.

$\mathrm{BOB}$ recently conducted a marine archaeological survey of a proposed pipeline project crossing Redfish Bay, in Nueces County. Project Consulting Services, Inc. contracted with BOB for this project, on behalf of the project sponsor, Axis Midstream Holdings, LLC. The survey spans portions of State Mineral Lease Tracts $321,324,325,326,327$, and 328 between the community of Aransas Pass and Harbor Island. The archaeology Area of Potential Effect encompasses 203 acres. A total of 299 acres was surveyed, including petroleum-industry access channels connected to each end of the main survey corridor and a 50-meter buffer around the proposed APE as mandated by the Texas Historical Commission. Water depth ranged from 2.911.7 feet during the survey. Field investigations included a marine geophysical survey, performed under Texas Antiquities Permit 8645, on November 16 and 17, 2018. BOB assessed all geophysical data acquired by the survey to locate potential archaeological sites that could be affected by construction-related activities. No artifacts were collected during this survey. A review of cultural background determined that 5 marine archaeological investigations and, at least, 9 wrecks have been reported within 3 miles of the survey area. Analysis of survey results discovered 3 significant geophysical targets that might be potentially eligible as State Antiquities Landmarks and for the National Register of Historic Places. BOB recommends avoidance of Anomalies 1,2 and 3 by $50 \mathrm{~m}(164 \mathrm{ft})$ beyond their 5-nT magnetic contours as mandated by THC guidelines. Portions of the APE located outside of anomaly avoidance zones are recommended for cultural resource clearance. Likewise, petroleum industry channels, located outside of the archaeology APE, are recommended for clearance, since those channels have been disturbed by dredging.

Please don't hesitate to contact me if you have any questions or concerns. I can be reached any time at $512-$ 517-8564 or by email at BOB.hydrographics@gmail.com.

All my best,

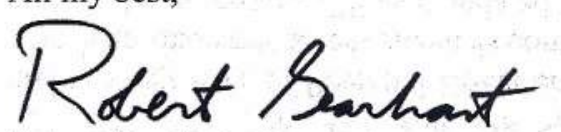

Robert Gearhart President

cc: Bob Ganczak, Project Consulting Services, Inc.

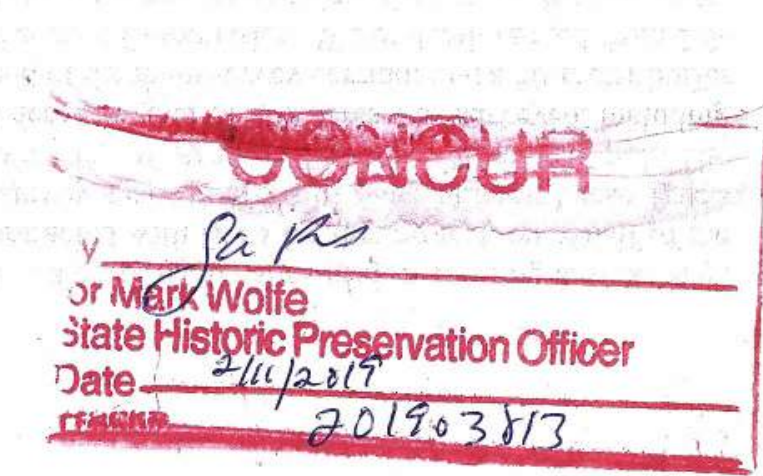

